\title{
Closely related Prochlorococcus genotypes show remarkably different depth distributions in two oceanic regions as revealed by in situ hybridization using 165 rRNA-targeted oligonucleotides
}

\author{
Nyree J. West, ${ }^{1}$ Wilhelm A. Schönhuber, ${ }^{2,3}$ Nicholas J. Fuller, ${ }^{1}$ \\ Rudolf I. Amann, ${ }^{2}$ Rosmarie Rippka, ${ }^{3}$ Anton F. Post ${ }^{4}$ \\ and David J. Scanlan ${ }^{1}$
}

1 Department of Biological Sciences, University of Warwick, Coventry CV4 7AL, UK

2 Max-Planck-Institut für Marine Mikrobiologie, Bremen, Germany

3 Unité de Physiologie Microbienne (CNRS URA 2172), Institut Pasteur, Paris, France

4 The H. Steinitz Marine Biology Laboratory, InterUniversity Institute of Eilat, Eilat, Israel

\begin{abstract}
Author for correspondence: David J. Scanlan. Tel: +44 2476 528363. Fax: +442476523701. e-mail: dscanlan@bio.warwick.ac.uk
\end{abstract}

\begin{abstract}
An in situ hybridization method was applied to the identification of marine cyanobacteria assignable to the genus Prochlorococcus using horseradishperoxidase-labelled 16S rRNA-targeted oligonucleotide probes in combination with tyramide signal amplification (TSA). With this method very bright signals were obtained, in contrast to hybridizations with oligonucleotides monolabelled with fluorochromes, which failed to give positive signals. Genotype-specific oligonucleotides for high light (HL)- and low light (LL)adapted members of this genus were identified by 165 rRNA sequence analyses and their specificities confirmed in whole-cell hybridizations with cultured strains of Prochlorococcus marinus Chisholm et al., 1992, Prochlorococcus sp. and Synechococcus sp. In situ hybridization of these genotype-specific probes to field samples from stratified water bodies collected in the North Atlantic Ocean and the Red Sea allowed a rapid assessment of the abundance and spatial distribution of HL- and LL-adapted Prochlorococcus. In both oceanic regions the LL-adapted Prochlorococcus populations were localized in deeper water whereas the HL-adapted Prochlorococcus populations were not only distinct in each region but also exhibited strikingly different depth distributions, HLI being confined to shallow water in the North Atlantic, in contrast to HLII, which was present throughout the water column in the Red Sea.
\end{abstract}

Keywords: cyanobacteria, Red Sea, oligonucleotide probes, 16S rRNA, TSA

\section{INTRODUCTION}

Members of the genus Prochlorococcus Chisholm et al., 1992 (Chisholm et al., 1992) are the most abundant photosynthetic organisms in the world's oceans due to their high cell densities and wide distribution within the

\footnotetext{
Abbreviations: DAPI, 4',6-diamidino-2-phenylindole; $\mathrm{HL}$, high light; $\mathrm{HRP}$ horseradish peroxidase; LL, low light; TETON, 4-(1,4,7,10-tetra-oxadecyl)1-naphthol; TSA, tyramide signal amplification.

The GenBank accession numbers for the sequences reported in this paper are AF311217 (RCC278, EQPAC1), AF311218 (RCC277, NATL1MIT), AF311219 (RCC280, NATL2B), AF311220 (RCC264, TAK9803-2), AF311291 (WH7803), AF311292 (WH8018) and AF311293 (WH8103).
}

$40^{\circ} \mathrm{N}-40^{\circ} \mathrm{S}$ latitudinal band (Partensky et al., 1999). The remarkable range of depths colonized by these oxygenic photosynthetic prokaryotes is achieved by the existence of multiple ecotypes which are adapted for growth in high-light (HL) or low-light (LL) environments (Ferris \& Palenik, 1998; Moore et al., 1998; Urbach \& Chisholm, 1998; West \& Scanlan, 1999). Although only a single species, Prochlorococcus marinus, the nomenclatural type, has been described on the basis of strain SS120 (Chisholm et al., 1992), the different light-dependent physiologies exhibited by this and numerous other isolates (Moore \& Chisholm, 1999; Moore et al., 1998) has led to the description of a new subspecies (Rippka et al., 2000). This is in agree- 
ment with comparative sequence analyses of $16 \mathrm{~S}$ rRNA genes which demonstrated that HL- and LL-adapted representatives of the genus form three distinct subclusters (HLI, HLII and LL) in phylogenetic trees (Moore et al., 1998; Urbach et al., 1998; West \& Scanlan, 1999). However, due to a lack of sufficient axenic strains no DNA-DNA hybridization studies are available to correlate $16 \mathrm{~S}$ rRNA gene sequence divergence with the boundaries of species. Hence, with the exception of the type strain, we shall refer to all isolates or genotypes of this genus as Prochlorococcus sp. Despite the relatively high similarity $(97 \cdot 3 \%)$ of the most distantly related HL and LL Prochlorococcus sp. genotypes (Moore et al., 1998), there are variable regions of the $16 \mathrm{~S}$ rRNA which can be targeted by oligonucleotides in order to distinguish them. In a recent study (West \& Scanlan, 1999), these genotype-specific probes were hybridized to PCRamplified Prochlorococcus sp. $16 \mathrm{~S}$ rDNA from natural samples. This confirmed the genetic distinctions between HL and LL ecotypes and revealed that nutrient concentrations and hydrological conditions may be important for their partitioning in surface and deep water, respectively.

Whilst the construction of $16 \mathrm{~S}$ rRNA gene clone libraries, dot-blot hybridization and denaturing gradient gel electrophoresis (DGGE) are valuable techniques to analyse natural communities and to provide a picture of microbial diversity, the processes of DNA extraction and PCR amplification may introduce biases (von Wintzingerode et al., 1997). Furthermore, the abundance of a particular genotype can only be expressed as a relative value. Whole-cell hybridization using $16 \mathrm{~S}$ rRNA-targeted oligonucleotides avoids these potential biases, allows the actual abundance of the genotype to be evaluated and also permits visualization of the spatial relationships of the cells in situ (Amann et al., 1997, 1995). For the majority of non-photosynthetic organisms, oligonucleotides monolabelled with a fluorescent dye are employed. However, for the hybridization of cyanobacteria, the signal from such probes has often been found to be insufficient to be visualized against the strong background of autofluorescence when viewed by epifluorescence microscopy (Schönhuber et al., 1999). Fluorescently labelled probes have been used successfully for hybridization of Synechococcus and Prochlorococcus cells (Binder \& Liu, 1998; Worden et al., 2000) when used in combination with flow cytometry and using a general bacterial probe EUB338 which targets one of the more accessible regions of the $16 \mathrm{~S}$ rRNA (Fuchs et al., 1998). However, for hybridization of Prochlorococcus cells, it was necessary to use peptide nucleic acid (PNA) probes since DNA probes gave poor results (Worden et al., 2000). Another method for improving the signal of hybridized cells is to use horseradish peroxidase (HRP)labelled probes combined with a fluorescent detection system based on tyramide signal amplification (TSA) (Schönhuber et al., 1997, 1999). Alternatively, hybridization with biotin-labelled probes and reaction with a streptavidin-HRP conjugate prior to detection using TSA, a more indirect hybridization protocol successfully employed for bacteria (Lebaron et al., 1997), should also overcome problems caused by autofluorescence. Here we report the use of a direct in situ hybridization method for members of the genus Prochlorococcus, initially optimized on cells of cultured isolates and then applied to the analysis of natural Prochlorococcus communities sampled from the North Atlantic and the Red Sea. Using a suite of $16 \mathrm{~S}$ rRNAtargeted oligonucleotides we extend previous work on the distribution and niche occupancy of specific Prochlorococcus genotypes and demonstrate that closely related high-light-adapted genotypes can show remarkably different depth distributions in these two oceanic regions.

\section{METHODS}

Strains and cultivation. The non-axenic Prochlorococcus marinus strain SS120 and Prochlorococcus sp. strains EQPAC1, TAK9803-2, NATL1MIT and NATL2B were obtained from the culture collection of the Station Biologique, Roscoff, France (culture collection numbers RCC156, RCC278, RCC264, RCC277 and RCC280, respectively). Strain PCC 9511 is axenic and was obtained from the Pasteur Culture Collection of Cyanobacteria (PCC) (Institut Pasteur, Paris, France). All strains were cultured in PCR-S11 medium (Rippka et al., 2000) as described previously (Scanlan et al., 1996). The axenic marine Synechococcus sp. strains WH7803 and WH8103, and the non-axenic marine Synechococcus sp. strain WH8018, were cultured in ASW medium (Wyman et al., 1985).

DNA sequencing and analysis. The $16 \mathrm{~S}$ rRNA gene sequences of the Prochlorococcus sp. strains EQPAC1, TAK9803-2, NATL1MIT and NATL2B were obtained after PCR amplification of two overlapping fragments using two separate pairs of primers: 27F (5'-AGAGTTTGATCMTGGCTCAG-3') and OXY1313R (5'-CTTCACGTAGGCGAGTTGCAGC$\left.3^{\prime}\right)$, and OXY107F (5'-GGACGGGTGAGTAACGCGTGR$\left.3^{\prime}\right)$ and 1518R (5'-AAGGAGGTGATCCANCCRCA-3'). Bidirectional sequencing was performed directly on the PCR products using an ABI 373A automated sequencer (Applied Biosystems). For the Synechococcus sp. strains WH7803, WH8018 and WH8103, 16S rRNA genes were amplified by the PCR using the primers $27 \mathrm{~F}$ and $1518 \mathrm{R}$ and inserted into the pCRII TA vector (Invitrogen). For the non-axenic Synechococcus sp. strain WH8018, clones containing cyanobacterial sequences were screened by PCR amplification with the primers OXY107F and OXY1313R. Clones were bidirectionally sequenced as described for the Prochlorococcus $16 \mathrm{~S}$ rRNA genes. Sequence alignment and phylogenetic analysis was carried out using the ARB sequence database tools (http://www.mikro.biologie.tu-muenchen.de/pub/ $\mathrm{ARB} /$ ). Initial analysis was carried out using the maximumlikelihood method, the maximum-parsimony method and evolutionary distance (Jukes and Cantor model for DNA) with almost full-length sequences, using 1364 positions after omitting positions where there were gaps, incomplete data or sequence ambiguity. Shorter sequences were then added in to each of the three resulting trees by the maximum-parsimony method. A consensus tree (based on the maximum-likelihood tree) was drawn to represent the combined results of the three trees and multifurcations were created when the branching order was not supported by all three methods. 
Table 1. Group- and genotype-specific $16 \mathrm{~S}$ rRNA oligonucleotide probes targeting marine cyanobacterial strains

Specificities of the probes used in this study are illustrated by an alignment of the probe and target sequences against Prochlorococcus marinus, Prochloroccus sp., Synechococcus sp. and other cyanobacterial $165 \mathrm{rRNA}$ sequences. Probe positions correspond to E. coli numbering (Brosius et al., 1981). Dots in the alignments indicate bases that are identical to those in the target sequence and dashes indicate a gap. Strains that are listed on the same line possess identical target sequences. GenBank accession numbers for $16 \mathrm{~S}$ rRNA sequences from Synechococcus sp. Biwa-B0, Synechococcus sp. Biwa-G0, Synechococcus sp. Biwa-P0, Oscillatoria neglecta M-82, Prochlorococcus sp. MIT9211, 'Microcystis holsatica' NIES43 and 'Microcystis elabens' NIES42 are D50614, D50615, D50616, AB003168, AF115270, U40335 and U40336 respectively. Some of the sequences of Prochlorococcus sp. and marine Synechococcus sp., and the environmental clone sequences included in this study, have been reported elsewhere (Moore et al., 1998; Rippka et al., 2000; Urbach \& Chisholm, 1998; West \& Scanlan, 1999).

\begin{tabular}{|c|c|c|c|c|c|c|c|c|c|c|c|c|c|}
\hline Probe 645HLI & $3^{\prime}-$ СТА & GCC & GAA & СтС & ATA & $\mathrm{CCA}-5^{\prime}$ & Probe 181HLI & $3^{\prime}-\mathrm{TAC}$ & GGC & TAT & CCA & CTT & TAC-5 \\
\hline Target (E. coli numbering 645-662) & $5^{\prime}-\mathrm{GAU}$ & CGG & CUU & GAG & UAU & GGU-3' & Target (E. coli numbering 181-198) & $5^{\prime}-\mathrm{AUG}$ & CCG & AUA & GGU & GAA & AUG-3' \\
\hline Prochlorococcus sp. PCC 9511/EQPAC1 (HLI) & $\cdots$ & $\cdots$ & $\cdots$ & $\cdots$ & $\cdots$ & $\cdots$ & Prochlorococcus sp. PCC 9511/EQPACl & $\ldots$ & $\ldots$ & $\ldots$ & $\ldots$ & $\ldots$ & $\ldots$ \\
\hline ENATL1 environmental clone (HLI) & $\cdots$ & $\cdots$ & $\cdots$ & $\cdots$ & $\cdots$ & $\cdots$ & ENATL1 environmental clone & $\cdots$ & $\cdots$ & $\cdots$ & $\cdots$ & $\cdots$ & $\cdots$ \\
\hline ENATL4 environmental clone (LL) & $\cdots$ & U. & $\cdots$ & $\cdots$ & $\cdots$ & $\cdots$ & ENATL4 environmental clone & $\cdots$ & $\cdots$ &. $\mathrm{G}$ & $\cdots$ & $\cdots$ & $\cdots$ \\
\hline Prochlorococcus sp. NATL1MIT/NATL2B (LL) & $\ldots$ & U. . & $\ldots$ & $\ldots$ & $\ldots$ & $\ldots$ & Prochlorococcus sp. NATL1MIT/NATL2B & $\ldots$ & $\ldots$ &. $\mathrm{G}$. & $\ldots$ & $\ldots$ & $\ldots$ \\
\hline Prochlorococcus sp. TAK9803-2 (HLII) & $\ldots A$ & A. . & $\ldots$ & $\ldots$ & $\ldots$ & $\ldots$ & /MIT9303/MIT9313 & & & & & & \\
\hline Prochlorococcus sp. MIT9303/MIT9313 (LL) & $\ldots$ & U. . & $\ldots$ & $\ldots$ &.$G$. & $\ldots$ & Prochlorococcus sp. MIT9211 & ... & $\cdots$ & .A. & $\cdots$ & $\cdots$ & $\cdots$ \\
\hline Prochlorococcus sp. MIT9211 (LL) & .U. & G. . & $\ldots$ & $\ldots$ &.$G$. & $\ldots$ & Prochlorococcus marinus SS120 & $\cdots$ & $\cdots$ &.$G$ & $\cdots$ & $\cdots$ & $\cdots$ \\
\hline Prochlorococcus marinus SS120 (LL) & $\ldots A$ & G. . & $\ldots \mathrm{C}$ & $\ldots$ &. $\mathrm{G}$ & $\ldots$ & Prochlorococcus sp. TAK9803-2 & $\cdots$ & $\ldots U$ &. $\mathrm{CU}$ & $\cdots$ & $\cdots$ & $\cdots$ \\
\hline Synechococcus sp. WH7803/WH8103 &. $\mathrm{U}$ & G. . & $\cdots$ & $\ldots$ &. $\mathrm{G}$ & $\ldots$ & Synechococcus sp. WH7805/WH7803/WH8018 & $\cdots$ & $\cdots$ &. $\mathrm{G}$ & $\cdots$ & $\cdots$ & $\cdots$ \\
\hline Synechococcus sp. WH8018 & U. & G. . & $\ldots \mathrm{C}$ & $\ldots$ &. $\mathrm{G}$. & $\cdots$ & Synechococcus sp. WH8103 & $\cdots$ & $\cdots$ & CG. & $\cdots$ & $\cdots$ & $\cdots$ \\
\hline Synechococcus sp. WH7805 &. $\mathrm{U}$ & G. . &. $\mathrm{NC}$ & . &. $\mathrm{G}$. & $\cdots$ & Synechococcus sp. WH8101 & $\ldots$ & $\ldots$ & CG. & $\ldots$ & $\ldots$ & .C. \\
\hline Synechococcus sp. WH8101 &. $\mathrm{U}$. & G. . & $\ldots \mathrm{A}$ & $\ldots$ &. $\mathrm{G}$. & $\ldots$ & Probe 181LL & $3^{\prime}-\mathrm{TAC}$ & GGC & TCT & $\mathrm{CCA}$ & СTT & TAC-5 \\
\hline Probe 645HLII & $3^{\prime}-\mathrm{CTT}$ & TCC & GAA & СтС & ATA & $\mathrm{CCA}-5^{\prime}$ & Target (E. coli numbering 181-198) & $5^{\prime}-\mathrm{AUG}$ & CCG & AGA & GGU & GAA & AUG $-3^{\prime}$ \\
\hline coli numbering 645-662) & $5^{\prime}-\mathrm{GAA}$ & AGG & $\mathrm{CUU}$ & GAG & $\mathrm{UAU}$ & GGU-3. & Prochlorococcus sp. NATL1MIT/NATL2B & $\cdots$ & $\cdots$ & $\cdots$ & $\cdots$ & $\cdots$ & $\ldots$ \\
\hline Prochlorococcus sp. TAK9803-2 & $\ldots$ & $\ldots$ & $\ldots$ & $\ldots$ & $\ldots$ & $\ldots$ & Prochlorococcus sp. MIT9303/MIT9313 & $\cdots$ & $\cdots$ & $\cdots$ & $\cdots$ & $\cdots$ & $\cdots$ \\
\hline Prochlorococcus sp. PCC 9511/EQPAC1 & $\ldots \mathrm{U}$ & C. . & $\cdots$ & $\cdots$ & $\cdots$ & $\cdots$ & Prochlorococcus marinus SS120 & $\cdots$ & $\cdots$ & $\cdots$ & $\cdots$ & $\cdots$ & $\cdots$ \\
\hline ENATL1 environmental clone & $\ldots \mathrm{U}$ & C. . & $\cdots$ & $\cdots$ & $\cdots$ & $\cdots$ & ENATL4 environmental clone & $\cdots$ & $\cdots$ & $\cdots$ & $\cdots$ & $\cdots$ & $\cdots$ \\
\hline ENATL4 environmental clone & $\ldots \mathrm{U}$ & U. . & $\ldots$ & $\ldots$ & $\ldots$ & $\ldots$ & Synechococcus sp. PCC 6307 & $\cdots$ & $\cdots$ & $\cdots$ & $\cdots$ & $\cdots$ & $\cdots$ \\
\hline Prochlorococcus sp. NATL1MIT/NATL2B & $\ldots \mathrm{U}$ & U. . & $\ldots$ & $\cdots$ & $\cdots$ & $\ldots$ & Synechococcus sp. WH7805/WH7803/WH8018 & $\cdots$ & $\cdots$ & $\cdots$ & $\cdots$ & $\cdots$ & $\cdots$ \\
\hline Prochlorococcus sp. MIT9303/MIT9313 & $\ldots \mathrm{U}$ & U. . & $\cdots$ & ... &. $\mathrm{G}$. & .. & Synechococcus sp. Biwa-B0/Biwa-G0/Biwa-P0 & $\cdots$ & $\cdots$ & $\cdots$ & $\cdots$ & $\cdots$ & $\cdots$ \\
\hline Prochlorococcus sp. MIT9211 &. $\mathrm{UU}$ & G. . & $\cdots$ & .. &. $\mathrm{G}$. & $\cdots$ & Oscillatoria neglecta $\mathrm{M}-82$ & $\cdots$ & $\cdots$ & $\cdots$ & $\cdots$ & $\cdots$ & $\cdots$ \\
\hline Prochlorococcus marinus $\mathrm{SS} 120$ & $\cdots$ & G. . & $\ldots \mathrm{C}$ & $\cdots$ &. $\mathrm{G}$ & $\cdots$ & Synechococcus sp. WH8103 & $\cdots$ & $\cdots$ & c.. & $\cdots$ & $\cdots$ & $\cdots$ \\
\hline Synechococcus sp. WH7803/WH8103 &. $\mathrm{UU}$ & G. . & $\ldots$ & $\ldots$ &. $\mathrm{G}$. & $\ldots$ & Prochlorococcus sp. MIT9211 & $\ldots$ & $\ldots$ & .A. & $\ldots$ & $\cdots$ & $\cdots$ \\
\hline Synechococcus sp. WH8018 &. $\mathrm{UU}$ & G. . & $\ldots \mathrm{C}$ & $\ldots$ &.$G$. & $\ldots$ & Prochlorococcus sp. PCC 9511/EQPACl & $\cdots$ & $\cdots$ &. $\mathrm{U}$ & .. & $\cdots$ & $\cdots$ \\
\hline Synechococcus sp. WH7805 &. $\mathrm{UU}$ & G.. &. $\mathrm{NC}$ & $\ldots$ &. $\mathrm{G}$. & $\ldots$ & ENATL1 environmental clone & $\cdots$ & $\cdots$ & . U. & .. & $\ldots$ & $\cdots$ \\
\hline Synechococcus sp. WH8101 &. $\mathrm{UU}$ & G.. & $\ldots A$ & $\ldots$ &.$G$. & $\ldots$ & Prochlorococcus sp. TAK9803-2 & ... & $\ldots \mathrm{U}$ &. $\mathrm{CU}$ & ... & ... & $\cdots$ \\
\hline Probe 645LL & $3^{\prime}-\mathrm{CTA}$ & ACC & GAA & CTC & ATA & $\mathrm{CCA}-5^{\prime}$ & Synechococcus sp. WH8101 & $\ldots$ & $\ldots$ & C. . & $\ldots$ & $\ldots$ & .C. \\
\hline Target (E. coli numbering 645-662) & $5-\mathrm{GAU}$ & UGG & $\mathrm{CUU}$ & GAG & $\mathrm{UAU}$ & GGU-3' & Probe 405PRO & $3^{-}-\mathrm{ACT}$ & $\mathrm{CCC}$ & TGC & TTC & CGG & $\mathrm{AGA}-5^{\circ}$ \\
\hline Prochlorococcus sp. NATL1MIT/NATL2B & $\cdots$ & $\ldots$ & $\ldots$ & $\ldots$ & $\ldots$ & $\ldots$ & Target (E. coli numbering 405-422) & $5-$ UGA & GGG & ACG & AAG & GCC & $\mathrm{UCU}-3^{\prime}$ \\
\hline ENATL4 environmental clone & $\cdots$ & $\cdots$ & $\cdots$ & $\cdots$ & $\cdots$ & $\cdots$ & Prochlorococcus sp. PCC 9511/EQPAC1/TAK9803-2/ & $\cdots$ & $\cdots$ & $\cdots$ & $\cdots$ & $\cdots$ & $\cdots$ \\
\hline Prochlorococcus sp. MIT9303/MIT9313 & .. & $\ldots$ & $\cdots$ & $\cdots$ &. $\mathrm{G}$. & .. & NATL1MIT/NATL2B & & & & & & \\
\hline Prochlorococcus sp. MIT9211 & .0 & G.. & $\cdots$ & $\cdots$ &. $\mathrm{G}$. & .. & ENATL1/ENATL4 environmental clones & $\cdots$ & $\cdots$ & $\cdots$ & $\cdots$ & $\cdots$ & $\cdots$ \\
\hline Prochlorococcus sp. TAK9803-2 & $\ldots$ A & A.. & $\ldots$ & $\cdots$ & $\ldots$ & $\cdots$ & Prochlorococcus marinus $\mathrm{SS} 120$ & .. & $\cdots$ & .0. & $\cdots$ & $\cdots$ & $\cdots$ \\
\hline Prochlorococcus sp. PCC 9511/EQPAC1 & $\cdots$ & C.. & $\cdots$ & $\ldots$ & $\ldots$ & $\ldots$ & Prochlorococcus sp. MIT9303/MIT9313/MIT9211 & .. & $\cdots$ & .0 . & $\cdots$ & $\cdots$ & $\cdots$ \\
\hline ENATL1 environmental clone & .. & C.. & $\cdots$ & $\cdots$ & $\cdots$ & $\cdots$ & Synechococcus sp. & $\cdots$ & $\cdots$ & $\cdot \mathrm{U}$ & $\cdots$ & $\cdots$ & $\cdots$ \\
\hline Prochlorococcus marinus SS120 & $\ldots$ A & G.. & . C & $\cdots$ & .G. & $\cdots$ & WH7803/WH7805/WH8103/WH8018/WH8101 & & & & & & \\
\hline Synechococcus sp. WH7803/WH8103 &. $\mathrm{U}$ & G. . & $\cdots$ & $\cdots$ & $\cdot \mathrm{G}$ & $\cdots$ & Probe 405SYN & $3^{\prime}-\mathrm{ACT}$ & CCC & TAC & TTC & CGG & $A G A-5^{\prime}$ \\
\hline Synechococcus sp. WH8018 &. $\mathrm{U}$ & G. . & $\ldots \mathrm{C}$ & $\cdots$ & $\cdot G$ & $\ldots$ & Target $(E$. coli numbering $405-422)$ & $5^{\prime}-\mathrm{UGA}$ & GGG & AUG & AAG & GCC & $\mathrm{UCU}-3^{\circ}$ \\
\hline Synechococcus sp. WH7805 &. $\mathrm{U}$ & G. . & $\cdot \mathrm{NC}$ & $\cdots$ &. $\mathrm{G}$. & $\cdots$ & Prochlorococcus marinus SS120 & $\cdots$ & $\cdots$ & $\cdots$ & $\cdots$ & $\cdots$ & $\cdots$ \\
\hline Synechococcus sp. WH8101 &. $\mathrm{U}$. & G.. & $\ldots \mathrm{A}$ & ... &. $\mathrm{G}$. & $\ldots$ & Prochlorococcus sp. MIT9303/MIT9313/MIT9211 & $\cdots$ & $\cdots$ & $\cdots$ & $\cdots$ & $\cdots$ & $\cdots$ \\
\hline Probe 1445NATL & $3^{\prime}-$ ATT & GGG & AAC & ACC & TCT & TCC-5 & $\begin{array}{l}\text { Synechococcus sp. } \\
\text { WH7803/WH7805/WH8103/WH8018/WH8101 }\end{array}$ & $\cdots$ & $\cdots$ & $\cdots$ & $\cdots$ & $\cdots$ & $\cdots$ \\
\hline Target $($ E. coli numb & $5^{\circ}-\mathrm{UAA}$ & $\mathrm{CCC}$ & UUG & UGG & AGA & AGG-3' & $\begin{array}{l}\text { WH7803/WH7805/WH8103/WH8018/WH8101 } \\
\text { Synechococcus sp. Biwa-B0/Biwa-G0/Biwa-P0 }\end{array}$ & & & & & & \\
\hline $\begin{array}{l}\text { Prochlorococcus sp. NATL1MIT } \\
\text { ENATL4 environmental clone }\end{array}$ & $\cdots$ & $\cdots$ & $\cdots$ & - & $\cdots$ & $\cdots$ & Synechococcus sp. PCC 6307 & $\cdots$ & $\cdots$ & $\cdots$ & $\cdots$ & & \\
\hline $\begin{array}{l}\text { ENATL4 environmental clone } \\
\text { Prochlorococcus sp. PCC } 9511 / \text { EQPAC1/TAK } 9803-2\end{array}$ & $\begin{array}{l}\text { No } \\
\text { C. }\end{array}$ & 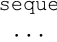 & ence & $\begin{array}{l}\text { data } \\
\ldots\end{array}$ & $\begin{array}{l}\text { ava } \\
\ldots G\end{array}$ & ailable & "Microcystis holsatica" NIES43/ & $\ldots$ & . & $\ldots$ & $\ldots$ & . & $\ldots$ \\
\hline Prochlorococcus sp. MIT9303/MIT9313/MIT9211 & C. . & . & $\cdots$ & $\cdots$ & $\begin{array}{l}\cdots G \\
\ldots G\end{array}$ & & "Microcystis elabens" NIES42* & & & & & & \\
\hline Synechococcus sp. WH8018/WH8101 & C. . & . . & $\ldots$ & $\cdots$ & $\ldots G$ & . & $\begin{array}{l}\text { Prochlorococcus sp. PCC 9511/EQPAC1/TAK9803-2/ } \\
\text { NATL1MIT/NATL2B }\end{array}$ & $\cdots$ & $\cdots$ & . C. & & & . \\
\hline Synechococcus sp. WH7803/8103 & C. . & $\cdots$ & .C. &..- & $\ldots \mathrm{G}$ & $\cdots$ & ENATL1/ENATL4 environmental clones & & & .C. & & & \\
\hline $\begin{array}{l}\text { Prochlorococcus marinus SS120/ } \\
\text { Synechococcus sp. WH7805 }\end{array}$ & No & sequ & ence & da & & ailab & & & & & & & \\
\hline
\end{tabular}

*See Results for contradictory identification of these strains.

Probes. The ARB sequence database tools were used for probe design and probe matching. The probe sequences and their specificities are shown in Table 1 . The bacterial probe EUB338 (5'-GCTGCCTCCCGTAGGAGT-3') (Amann et al., 1990) and the oligonucleotide NON338 (5'-ACTCCTACGGGAGGCAGC-3') (Wallner et al., 1993), which served respectively as positive and negative controls, were monolabelled with the fluorochromes CY3 and BODIPY-FL (Interactiva).

For hybridizations carried out with HRP-labelled probes, probe CYA664 (5'-GGAATTCCCTCTGCCCC-3') (Schönhuber et al., 1999) and the oligonucleotide NON338 were employed as positive and negative controls, respectively. Probe CYA664 targets all known marine Synechococcus sp. and Prochlorococcus sp., which fall into the marine picophytoplankton clade (Urbach et al., 1998), several genera of filamentous cyanobacteria (Schönhuber et al., 1999) and some chloroplasts. Oligonucleotides with a C6-aminolink (Interactiva) were labelled with HRP as described previously (Amann et al., 1992; Urdea et al., 1988).

Cell fixation of cultured isolates. Prochlorococcus and Synechococcus cells (approx. $2 \mathrm{ml}$ of liquid cultures) were pelleted by centrifugation (10000 $\mathrm{g}, 5 \mathrm{~min}$ ) and resuspended in $200 \mu \mathrm{l}$ PBS 
(130 mM sodium chloride, $10 \mathrm{mM}$ sodium phosphate buffer, $\mathrm{pH} 7 \cdot 2)$. Fixation was performed either by mixing immediately with 1 vol. ethanol $(96 \%, v / v)$ or by adding paraformaldehyde $(4 \%, w / v$, in PBS) to a final concentration of $3 \%(w / v)$ and incubation for $1 \mathrm{~h}$ on ice. After fixation with paraformaldehyde, the cells were washed once with PBS, resuspended in the same buffer and then mixed with 1 vol. ethanol $(96 \%$, $\mathrm{v} / \mathrm{v})$. The fixed samples were stored at $-20^{\circ} \mathrm{C}$.

Sampling and fixation of natural samples. Water samples from the North Atlantic Ocean were collected from discrete depths $(3,20,30,40,60,80$ and $100 \mathrm{~m})$ on 14 July $\left(36.82^{\circ} \mathrm{N}\right.$, $19 \cdot 24^{\circ} \mathrm{W}$; Station 25$)$ and 15 July $\left(36.63^{\circ} \mathrm{N}, 19 \cdot 24^{\circ} \mathrm{W}\right.$; Station 26) 1996 with a rosette of 25-litre Go-Flo bottles during a Natural Environment Research Council, Plankton Reactivity in the Marine Environment (PRIME) cruise, aboard the RRS Discovery. Aliquots $(1 \mathrm{ml})$ were immediately fixed by adding glutaraldehyde to a final concentration of $0 \cdot 1 \%(\mathrm{v} / \mathrm{v})$ prior to freezing in liquid nitrogen.

Samples from the Red Sea were also taken from discrete depths $(10,30,50,80,100$ and $150 \mathrm{~m})$ on 18 October 1999 at Station A $\left(29.28^{\circ} \mathrm{N}, 34.55^{\circ} \mathrm{E}\right)$ (Lindell \& Post, 1995) using a hydrographic cable with 30 -litre Niskin bottles. Samples were fixed in two different ways: (i) $100 \mathrm{ml}$ seawater (for depths 10 , 30,50 and $80 \mathrm{~m}$ ) or $150 \mathrm{ml}$ seawater (for depths 100 and $150 \mathrm{~m}$ ) were vacuum-filtered onto polycarbonate membranes (GTTP 4700, 0.2 $\mu \mathrm{m}$ pore size, Millipore) using a filter tower with a diameter of $40 \mathrm{~mm}$ and the cells were fixed by overlaying the membranes for $1 \mathrm{~h}$ with $5 \mathrm{ml}$ paraformaldehyde $(1 \%, w / v)$. The fixative was then drawn through the membrane and washed with $5 \mathrm{ml}$ PBS. (ii) $50 \mathrm{ml}$ seawater was fixed with glutaraldehyde $(0 \cdot 1 \%, \mathrm{v} / \mathrm{v}$, final concentration) for $10 \mathrm{~min}$ at $4{ }^{\circ} \mathrm{C}$. The paraformaldehyde-fixed filters and the $50 \mathrm{ml}$ glutaraldehyde-fixed liquid samples were then stored at $-20{ }^{\circ} \mathrm{C}$.

Flow cytometric data for Prochlorococcus, Synechococcus and heterotrophic bacteria cell numbers were obtained as described previously (Jacquet et al., 1998).

\section{In situ hybridization}

Preparation of cells of cultured Prochlorococcus and Synechococcus strains. Fixed cells of cultured Prochlorococcus and Synechococcus strains were spotted into wells on microscope slides (Paul Marienfeld KG, Germany), dried at $45^{\circ} \mathrm{C}$ for $5 \mathrm{~min}$ and then dehydrated in an ethanol series, $50 \%, 80 \%$ and $96 \%$ (v/v), for 3 min each. The slides were then air-dried and the cells permeabilized by adding $30 \mu \mathrm{l}$ lysozyme solution [ 1 or $5 \mathrm{mg} \mathrm{ml}^{-1}$ of lysozyme (109000 $\mathrm{U} \mathrm{mg}^{-1}$; Fluka) dissolved in $100 \mathrm{mM}$ Tris $/ \mathrm{HCl}$ ( $\mathrm{pH} \mathrm{8.0)}, 50 \mathrm{mM}$ EDTA] and incubating for $30 \mathrm{~min}$ at $37^{\circ} \mathrm{C}$. After rinsing the slides with distilled water, the cells were dehydrated as described above.

Preparation of natural samples. For in situ hybridization of the North Atlantic samples, aliquots $(400 \mu \mathrm{l})$ of the glutaraldehyde-fixed samples were filtered onto polycarbonate filters (GTTP 2500; $0 \cdot 2 \mu \mathrm{m}$ pore size; Millipore) using a filter tower with a diameter of $5 \mathrm{~mm}$. The filters were then washed once with $1 \mathrm{ml}$ PBS and divided into quarters. For the Red Sea glutaraldehyde-fixed samples, each sample $(50 \mathrm{ml})$ was filtered onto a single polycarbonate filter, but using a filter tower with a diameter of $20 \mathrm{~mm}$. After filtration, the filters were washed with $2 \mathrm{ml}$ PBS. Further treatment was as described for cultured strains except that the first ethanol dehydration step was omitted.

Hybridization with fluorescently labelled probes. Hybridizations with fluorochrome-labelled probes were performed as de- scribed previously (Manz et al., 1992). The fluorochromelabelled probes EUB338 and NON338 were hybridized in buffer containing $20 \%(\mathrm{v} / \mathrm{v})$ formamide.

Hybridization with HRP-labelled probes. The hybridization procedure was based on those described previously (Amann et al., 1992; Schönhuber et al., 1999). Each well on the microscope slide or filter portion was overlaid with $10 \mu \mathrm{l}$ hybridization buffer $[0.9 \mathrm{M} \mathrm{NaCl}, 20 \mathrm{mM}$ Tris/ $\mathrm{HCl}(\mathrm{pH} 7 \cdot 2), 0 \cdot 01 \%$ (w/v) SDS and $2 \%$ blocking reagent (Boehringer Mannheim)] which contained $50 \mathrm{ng}$ of an HRP-labelled probe and different concentrations of formamide depending on the probe used. The formamide concentrations used in hybridizations with the HRP-labelled probes were as follows: 405PRO, 405SYN and 1445 NATL, $60 \%$; 645HLI, 181HLI, 181LL and CYA664, $55 \%$; 645HLII, 645LL and NON338, 50\%. Probe NON338 was always used as a negative control in hybridizations with cultured Prochlorococcus and Synechococcus strains and with environmental samples. Slides were incubated in humid chambers at $35^{\circ} \mathrm{C}$ for $2 \mathrm{~h}$ and then washed at the same temperature for $30 \mathrm{~min}$ in $50 \mathrm{ml}$ wash buffer $[20 \mathrm{mM}$ Tris/ $\mathrm{HCl}$ (pH 7.2), $5 \mathrm{mM}$ EDTA, $0 \cdot 01 \%$ (w/v), SDS] containing $\mathrm{NaCl}$ at molarities equivalent to the formamide concentrations present in the hybridization buffer $(0.019 \mathrm{M}, 0.013 \mathrm{M}$ and no $\mathrm{NaCl}$ for formamide concentrations of $50 \%, 55 \%$ and $60 \%, \mathrm{v} / \mathrm{v}$, respectively). Hybridization of HRP-labelled probes was detected initially by incubation with the nonfluorescent substrate TETON [4-(1,4,7,10-tetraoxadecyl)-1naphthol; Boehringer Mannheim] as described previously (Schönhuber et al., 1999). For detection with the fluorescent substrate fluorescein-tyramide (Schönhuber et al., 1997, 1999), slides were first equilibrated in TNT buffer $[0 \cdot 1 \mathrm{M}$ Tris $/ \mathrm{HCl}$ $(\mathrm{pH} 7 \cdot 5), 0 \cdot 15 \mathrm{M} \mathrm{NaCl}, 0 \cdot 05 \%$ (v/v), Tween 20] for $15 \mathrm{~min}$ at room temperature. After drying around each well/filter portion, $10 \mu \mathrm{l}$ fluorescein-tyramide substrate solution $[1: 1$ ratio of amplification diluent (a constituent of the TSA kit) and $40 \%(\mathrm{w} / \mathrm{v})$, dextran sulphate with $1 / 50$ vol. fluoresceintyramide] was added to each well/filter and then incubated at room temperature in the dark for $10-60 \mathrm{~min}$. The wells or filters were then carefully rinsed with distilled water and washed in TNT buffer at $55^{\circ} \mathrm{C}$ for $10 \mathrm{~min}$. After a final rinse in distilled water, the slides were dried and mounted in a $4: 1$ mixture respectively of Citifluor (Agar Scientific) and Vectashield (Vector Laboratories). Filters were stained with 4',6diamidino-2-phenylindole (DAPI) prior to mounting (see 'Counting on filters' section). Slides were examined using either a Zeiss Axiophot2 microscope (Carl Zeiss) equipped for epifluorescence with a high-pressure mercury bulb (100 W) and specific filter sets 01 (excitation 365/12 nm, emission LP $397 \mathrm{~nm}$ ) and 09 (excitation BP450-490, emission LP $520 \mathrm{~nm}$ ) (Carl Zeiss) and Chroma HQ 41007 (Chroma Tech.), or an Olympus BX-60 microscope (Olympus Optical) equipped with a high-pressure mercury bulb $(100 \mathrm{~W})$ and specific filter sets U-MWU (excitation BP330-385 nm, BA420 nm) and UMNB (excitation BP470-490 nm, BA515 nm) (Olympus Optical). Epifluorescence micrographs and phase-contrast images were captured onto Kodak film P1600X. The epifluorescence micrographs of cells hybridized with a positive or negative probe were taken at the same exposure in order to provide a fair comparison.

Counting on filters. To obtain total bacterial counts filters were counterstained with DAPI following hybridization. Filters were stained for 7 min with a solution (about $5 \mu \mathrm{l}$ ) of DAPI at a concentration of $1 \mu \mathrm{g} \mathrm{ml}^{-1}$ in water and then rinsed briefly by dipping in sterile distilled water, followed by $96 \%$ $(\mathrm{v} / \mathrm{v})$ ethanol. Filters were air-dried and placed onto glass slides in the mounting medium described above. For the North 
Atlantic samples, 20 randomly chosen fields of view were counted using the DAPI filter set to enumerate total cells and the fluorescein filter set for the probe-specific cell counts. For each microscope field, probe-specific counts were expressed as a percentage of the total cells visualized by DAPI and the mean abundance and standard deviation calculated from these values. The total numbers of cells counted per filter ranged from 360 to 1280 . For the Red Sea samples, for which greater volumes of sample were available, 10 randomly chosen fields of view were counted in the same way as for the North Atlantic samples and the total number of cells counted per filter was at least 1400. Filters for which no signals were observed after inspecting at least 20 random fields of view were deemed negative and were not counted.

\section{RESULTS}

\section{Probe design}

The new 16S rRNA sequences determined for four Prochlorococcus and three Synechococcus strains were compared with other sequences available for these genera and the results presented as a phylogenetic tree (Fig. 1). For the genus Prochlorococcus, strain EQPAC1 clustered with HLI genotypes, whereas TAK9803-2 was assignable to the HLII cluster and NATL1MIT and NATL2B proved to be LL genotypes. The three Synechococcus isolates (WH7803, WH8018 and WH8103) clustered as expected with two other marine members of this genus (Fig. 1). The strains targeted by each probe are indicated by the brackets to the right of the tree (Fig. 1). Genotype-specific probes for members of the genus Prochlorococcus were mainly targeted to two regions of the $16 \mathrm{~S}$ rRNA corresponding to Escherichia coli positions 181-198 and 645-662, which allow discrimination between the HL- and the LLadapted phylogenetic clusters within this genus (Urbach et al., 1998; West \& Scanlan, 1999). The probes designated 645 (Table 1) are in part based on the sequence positions previously employed for specific identification (West \& Scanlan, 1999), but are shifted 11 nucleotides towards the 3 '-end of the $16 \mathrm{~S}$ rRNA gene, a region potentially more accessible in whole-cell hybridizations (Fuchs et al., 1998). The genotype-specific probes targeted to the 645 region of the $16 \mathrm{~S}$ rRNA are fully complementary to isolates assignable to phylogenetic subclusters (HLI, HLII or LL) (Fig. 1), with the exception of 645LL, which excludes some LL Prochlorococcus strains (Table 1). For the 181 target region, 181HLI targets specifically all HLI strains, whereas probe $181 \mathrm{LL}$, although fully complementary to all LLadapted strains, also recognizes a few other cyanobacterial sequences (Table 1). However, in the marine environments inhabited by representatives of the genus Prochlorococcus only a few other cyanobacterial species are known to coexist, notably Synechococcus spp. (Partensky et al., 1999) and Trichodesmium spp. (Capone et al., 1997). The latter species can be readily distinguished from the genus Prochlorococcus by their filamentous morphology. Synechococcus sp. cells are generally larger than those of Prochlorococcus and so in environments where Synechococcus is also abundant, it would be necessary to discriminate subjectively between Prochlorococcus and Synechococcus cells on the basis of size when hybridizing with 181LL. Consequently in this case, it is important to compare the counts obtained following hybridization with all of the genotype-specific probes in order to specifically enumerate the Pro-

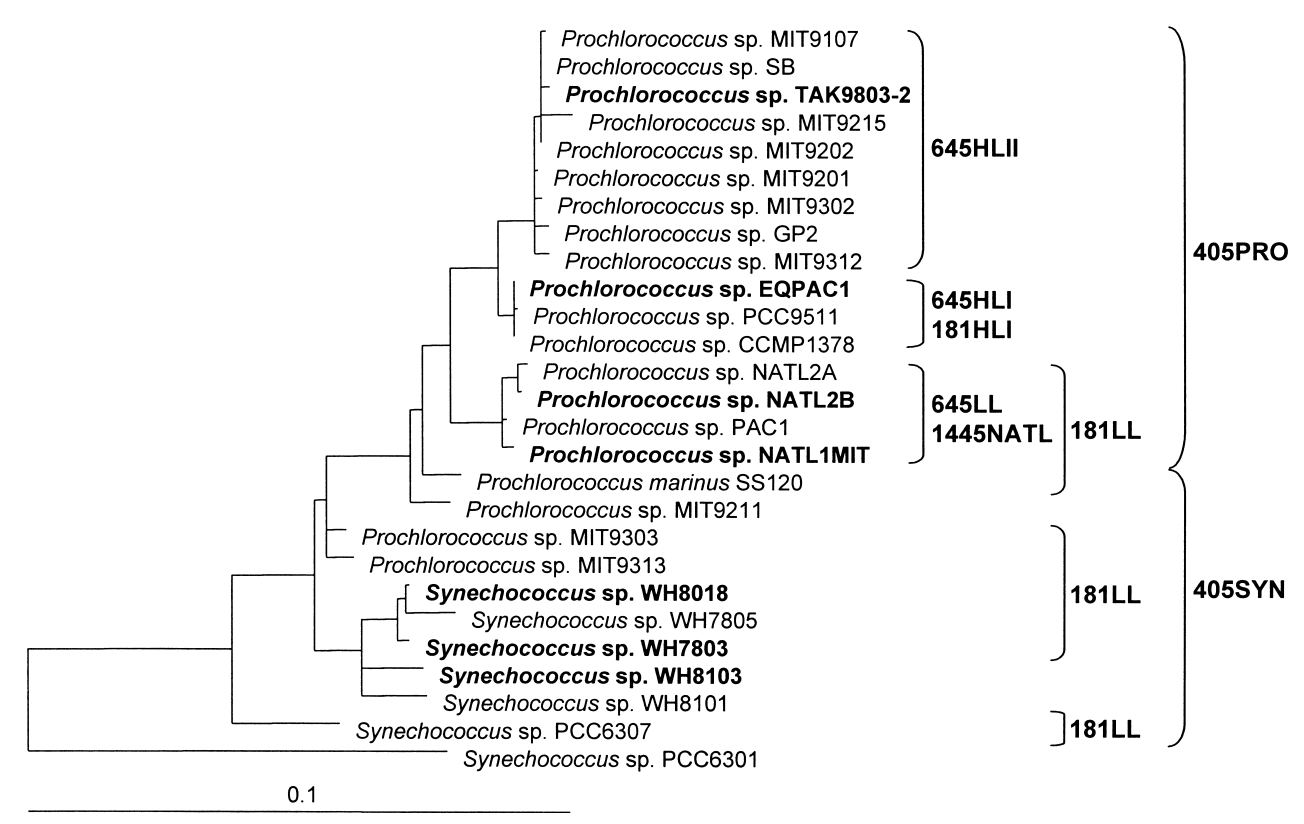

Fig. 1. Consensus tree showing the phylogenetic relationships amongst Prochlorococcus sp. and Synechococcus sp. The initial analysis was based on 1364 positions, and shorter sequences were subsequently added by the maximum-parsimony method. The scale bar represents $10 \%$ estimated sequence divergence. The $16 \mathrm{~S}$ rRNA sequences obtained from strains in this study are shown in bold. Strains targeted by the probes are bracketed. 
chlorococcus LL genotype. The advantage of probe 181LL over probe 645LL is that it is fully complementary to all known LL-adapted isolates of the genus Prochlorococcus presently in culture. An additional probe, 1445 NATL, was designed to target the same cluster of LL genotypes as recognized by 645LL. This region is advantageous since the target region is probably more accessible (Fuchs et al., 1998). Based on the comparison of the almost full-length $16 \mathrm{~S}$ rRNA gene sequences available for Prochlorococcus and bacteria, probe 1445 NATL is specific for the LL genotypes. However, sequence data for this specific region is relatively limited and thus this probe should be used in parallel with the other LL-targeted probes. Probe 405PRO is fully complementary to the target sites of the majority of Prochlorococcus sp. strains sequenced to date but has a single mismatch with respect to those of Prochlorococcus marinus SS120, Prochlorococcus sp. MIT9303, MIT9313 and MIT9211 (all LL genotypes), (Moore et al., 1998; West \& Scanlan, 1999) and to all known marine Synechococcus sp. (see Table 1). Probe $405 \mathrm{SYN}$ is the Synechococcus counterpart to 405PRO and targets the majority of marine Synechococcus strains and a few freshwater Synechococcus strains, but also the Prochlorococcus strains Prochlorococcus marinus SS120, MIT9303, MIT9313 and MIT9211. Although 405SYN targets two strains designated as 'Microcystis holsatica' NIES43 and 'Microcystis elabens' NIES42, there is evidence to suggest that they should be reclassified as Synechococcus sp. since 16S rRNA comparisons have placed them within one of the Synechococcus clusters (Neilan et al., 1997) and they also lack gas vesicles (Otsuka et al., 1998). Probe 405PRO was used in parallel with probe CYA664 (Schönhuber et al., 1999) to estimate the total number of cells representative of the genus Prochlorococcus in the natural samples (Tables 2 and 3).

\section{Whole-cell hybridization with fluorescently labelled oligonucleotides}

Since all representatives of the genus Prochlorococcus exhibit dim autofluorescence compared to those of the marine Synechococcus genus, whole-cell hybridizations with cultured isolates of Prochlorococcus were initially carried out using oligonucleotides EUB338 and NON338 monolabelled with the fluorochromes CY3 and BODIPY-FL. Although these fluorochromes are amongst the brightest that are currently available (Glöckner et al., 1996), no appreciable difference was observed between cells hybridized with a positive and negative probe despite permeabilization with variable concentrations of lysozyme. The heterotrophic bacteria present in the non-axenic Prochlorococcus and Synechococcus cultures, however, did give good signals with the CY3-labelled probe EUB338 and hence acted as positive controls for the hybridization constituents and conditions (data not shown).

In order to improve the positive: negative probe signal ratio, HRP-labelled oligonucleotides were used in hybridizations with Prochlorococcus cells. With this approach the hybridization signal is amplified by the activity of the probe-conferred enzyme, leading to a deposit of multiple substrate molecules in the cell.

\section{Whole-cell hybridization using HRP-labelled oligonucleotides}

Probe CYA664, which is complementary to $16 \mathrm{~S}$ rRNA gene sequences of all known Prochlorococcus and marine Synechococcus strains and to some chloroplasts (Schönhuber et al., 1999), was initially employed as an alternative to probe EUB338 to test the utility of HRPlabelled oligonucleotides for whole-cell hybridizations with cultured strains. As for EUB338, its target region in the $16 \mathrm{~S}$ rRNA of E. coli is readily accessible (Fuchs et al., 1998). Hybridization was detected using either the nonfluorescent substrate TETON or the fluorescent substrate fluorescein-tyramide. With the former, revealing hybridization by production of a blue precipitate, no positive results were obtained. In contrast, a $10 \mathrm{~min}$ incubation with the fluorescein-tyramide substrate yielded extremely bright green single-cell hybridization signals with all strains examined (see for example Fig. 2e, left panel).

The conditions of optimal pre-treatment for successful hybridizations of whole cells in members of the genus Prochlorococcus and Synechococcus were determined by varying the fixation procedures and by incubating the fixed cells with different concentrations of lysozyme. The brightest signals were obtained when cells were fixed with paraformaldehyde and treated with lysozyme (1 or $5 \mathrm{mg} \mathrm{ml}^{-1}$ ), although the latter treatment was not strictly necessary with cultured isolates. However, in order to obtain the best signals, subsequent hybridizations on cultured isolates were all carried out on cells fixed with paraformaldehyde and treated with $5 \mathrm{mg}$ lysozyme $\mathrm{ml}^{-1}$ following fixation.

\section{Evaluation of probe specificities}

The optimal hybridization conditions were determined for all of the genotype-specific probes listed in Table 1 by hybridizing each of them to cells of all of the cultured Prochlorococcus and Synechococcus strains (see section above) at different formamide concentrations (30, 40, $50,55$ and $60 \%)$. Although the target $16 \mathrm{~S}$ rRNA sequence among the strains examined often differed by a single mismatch only, specific hybridization for each probe was clearly observed at formamide concentrations of 50,55 or $60 \%$ (see Methods for probe-specific formamide concentrations). Hybridizations were performed at the optimal formamide concentrations at least twice and the specificity of each probe was consistently observed. The clear difference between a positive and negative hybridization signal is shown in Fig. 2(a-e), where three Prochlorococcus strains representative of HLI, HLII and LL genotypes respectively and two Synechococcus strains were each hybridized with a positive (left panel) and negative probe (right panel). 
The autofluorescence of the Prochlorococcus cells hybridized with the negative probe was very low (Fig. $2 \mathrm{a}-\mathrm{c}$, right panel) in contrast to Synechococcus cells, which showed significant yellow/orange autofluorescence (Fig. 2d and e, right panel). Despite the strong autofluorescence of the Synechococcus cells, the difference between a negative signal (yellow/orange) and a positive signal (green) could clearly be observed. Each epifluorescence photomicrograph has been presented beside the corresponding phase-contrast image to demonstrate the efficient labelling of all cells. The signal intensities observed for each probe were very similar, in spite of potentially more difficult accessibility of the 645 target site compared to that of the 181 region of the $16 \mathrm{~S}$ rRNA (Fuchs et al., 1998). Figs 2(a) and 2(c) (right panels) demonstrate the specificity of the 181LL and 645 HLI probes respectively, which both distinguish between Prochlorococcus sp. PCC9511 and NATL1MIT by only a single mismatch in the respective rRNA target sites (Table 1). Furthermore, probe 181LL did not hybridize to Synechococcus sp. strain WH8103 despite there also being only a single mismatch between the $16 \mathrm{~S}$ rRNA sequence and the probe (Fig. 2e). The 16S rRNA sequences of some marine Synechococcus strains are targeted by probe 181LL (see Table 1) and give a positive hybridization signal as illustrated for strain WH8018 (Fig. 2d).

\section{Application of probes to identify Prochlorococcus sp. genotypes in the North Atlantic and the Red Sea}

The seawater samples available to us from the North Atlantic had originally been fixed with glutaraldehyde for flow cytometric analysis. Nevertheless, preliminary hybridizations with selected samples from different depths of Station 26 in the North Atlantic yielded very bright signals when using probes CYA664 and 405PRO. For the genotype-specific probes the signals were lower and the order of brightness was subjectively assessed as: 181LL > 645HLI > 645LL. Since hybridization of probe $181 \mathrm{HLI}$ to the filters resulted in a high background that masked positive signals, this probe was not used further. No positive signals were observed by hybridization of probe 645 HLII to all of the samples from Stations 25 and 26. Some larger cells were observed after hybridization to probe CYA664 and these cells were believed to be representatives of Synechococcus. The number of these cells was very low, consistent with flow cytometric data for the days sampled at either side of Stations 25 and 26, which indicated that Prochlorococcus sp. accounted for approximately $80-97 \%$ of the total picophytoplankton (West \& Scanlan, 1999).

The first results of enumerating hybridizing cells as the fraction (mean $\pm \mathrm{SD}$ ) of total bacterial counts by DAPI staining from different depths (3,20 and $40 \mathrm{~m}$ ) of Station 25 in the North Atlantic Ocean are shown in Table 2. The mean fraction of cells collected from 20 and $40 \mathrm{~m}$ and hybridizing with the two general probes CYA664 and 405PRO were very similar. This suggests, in agreement with previous data (West \& Scanlan, 1999), that the cyanobacterial community in these water columns is almost entirely composed of members of the genus Prochlorococcus, which are all recognized by probe $405 \mathrm{PRO}$. For the $3 \mathrm{~m}$ sample, there was also good agreement between the mean fraction of cells hybridizing with probe $645 \mathrm{HLI}$ compared to probes CYA664 and 405PRO, suggesting that the genotypes detected were almost entirely assignable to the HLI cluster. However, for the deeper samples (20 and $40 \mathrm{~m}$ ) the sum of cells detected by the 645HLI and 645LL genotype-specific probes only accounted for about $50 \%$ of the total mean fraction of Prochlorococcus sp. determined with probes CYA664 and 405PRO, one or both of the two genotypes evidently being underestimated. Indeed, the signal intensities observed in samples from deeper depths with both genotype-specific probes were lower than those obtained for the $3 \mathrm{~m}$ sample, which no doubt contributed to the lower counts. These initial hybridizations on filters were carried out using a fluorescein-tyramide incubation time of $30 \mathrm{~min}$. In an attempt to improve the signals with the genotypespecific probes, subsequent substrate incubation times were extended to $1 \mathrm{~h}$. Additionally, probe 181LL was selected for hybridizations in preference to probe 645LL, since it gave higher signals (see above). With these changes, the mean fraction of total Prochlorococcus sp. detected by CYA664 and the sum of genotype-specific fractions were in much better agreement. This is shown in Table 2, both for a sample from $80 \mathrm{~m}$ at Station 25 and for all samples of Station 26. The typical signals observed by hybridization with probes 645HLI and 181LL, following the improved protocol, are shown in Fig. 3(a) and Fig. 3(b). For the $80 \mathrm{~m}$ sample of Station 25 , probe $181 \mathrm{LL}$ detected $70 \%$ of the mean fraction of cells identified by the CYA664 probe. The results for the samples from Station 26 showed an even better agreement between the enumerations made with the two genotype-specific probes, which together accounted for $87-95 \%$ of the mean fraction determined by hybridizations with probe CYA664. A comparison of the hybridization results and enumerations made by DAPI staining indicate that at both stations HLI-adapted Prochlorococcus sp. dominated the surface water, representing approximately $25 \%$ of the total bacterial counts, whereas at $80 \mathrm{~m}$, the LL-adapted genotypes were dominant and the proportion of both genotypes together decreased to about $14 \%$ of total counts. Additionally, at a depth of $40 \mathrm{~m}$ at Station 25, both HLI- and LL-adapted Prochlorococcus sp. genotypes were detected.

Following the analysis of the North Atlantic samples, two further probes were designed: 1445NATL to be used in parallel with 181LL, and 405SYN to allow estimation of the Synechococcus sp. cell abundance. 1445NATL and 405SYN were then used together with 645HLI, 645HLII, 181LL, 405PRO and CYA664 for hybridization with the Red Sea samples. The seawater samples had been fixed in two different ways, with paraformaldehyde or glutaraldehyde, to determine the optimum fixation conditions for natural samples. Test hybridizations showed that consistently good hybridization signals were obtained with seawater 
(a)

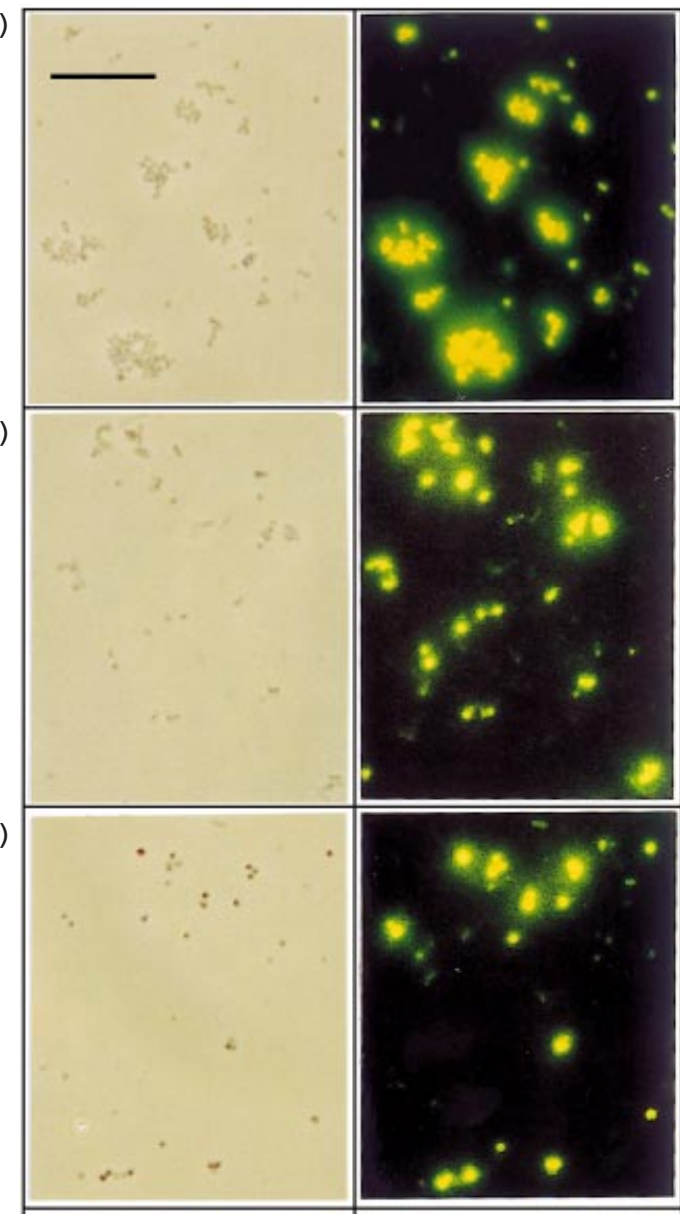

(d)

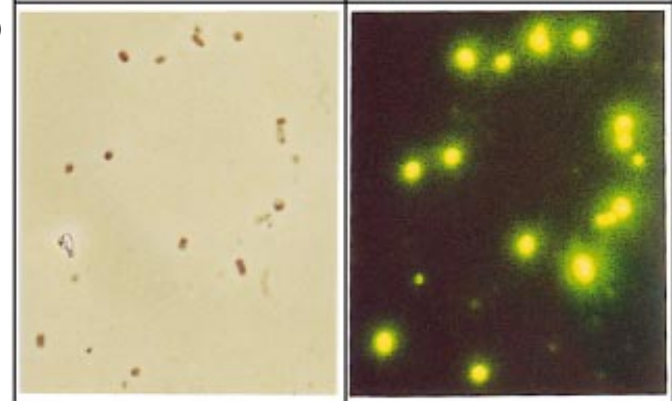

(e)
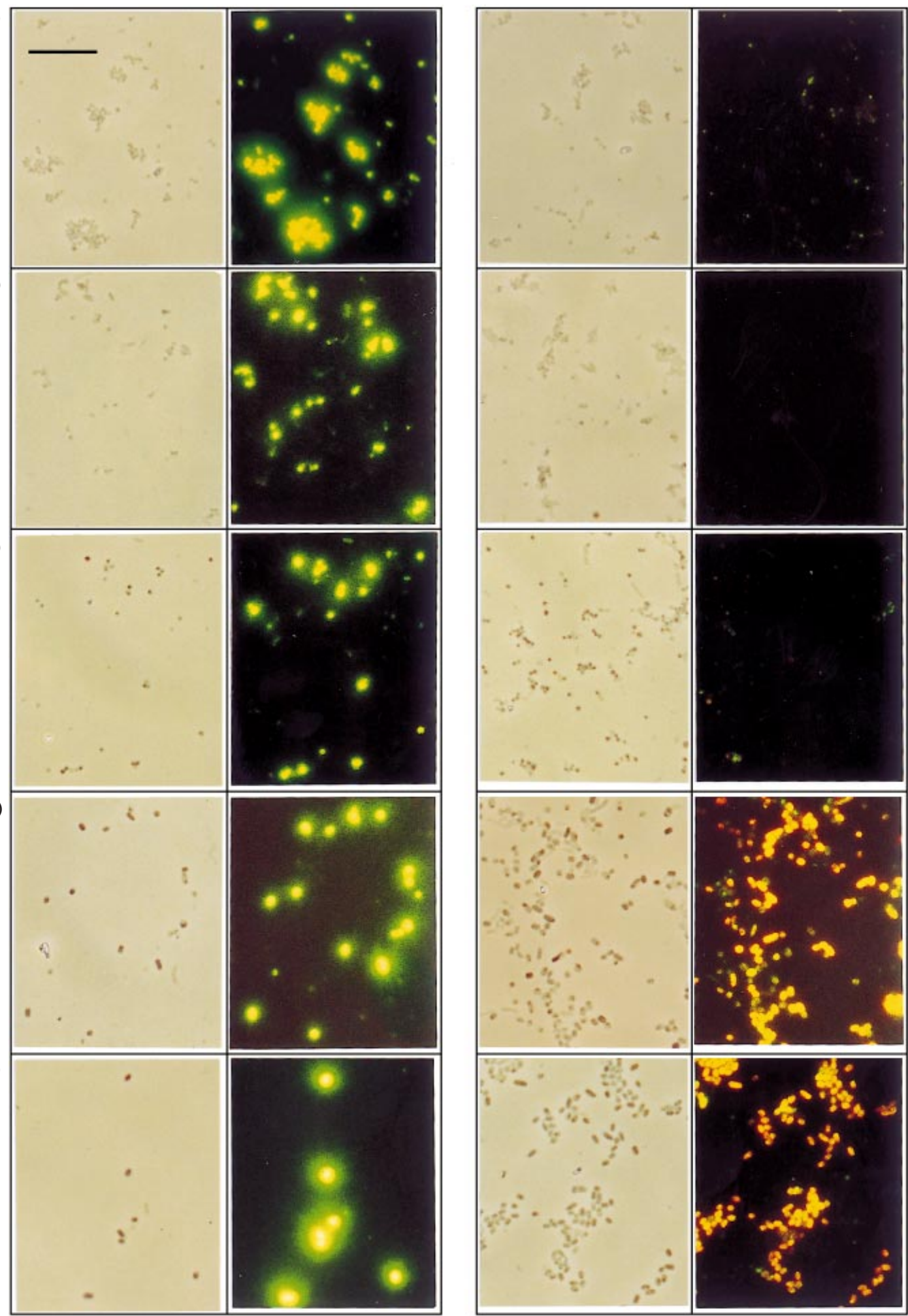

Fig. 2. Colour micrographs of Prochlorococcus and Synechococcus strains after hybridization with a positive probe (left panels) or a negative probe (right panels). Each panel shows a phase-contrast image with its corresponding epifluorescence image (filter set U-MNB) to the right. (a) Prochlorococcus sp. strain PCC 9511 (HLI genotype) hybridized with probe $645 \mathrm{HLI}$ (left panel) and 181LL (right panel). (b) Prochlorococcus sp. TAK9803-2 (HLIl genotype) hybridized with probe $645 \mathrm{HLII}$ (left panel) and 181LL (right panel). (c) Prochlorococcus sp. NATL1MIT (LL genotype) hybridized with probe 181LL (left panel) and 645HLI (right panel). (d) Synechococcus sp. strain WH8018 hybridized with probe 181LL (left panel) and $645 \mathrm{HLI}$ (right panel). (e) Synechococcus sp. strain WH8103 hybridized with probe CYA664 (left panel) and 181LL (right panel). Bar, $10 \mu \mathrm{m}$. 
Table 2. Relative proportions of HLI and LL Prochlorococcus sp. genotypes and total Prochlorococcus, as a percentage of total bacteria for two depth profiles in the North Atlantic Ocean

\begin{tabular}{|c|c|c|c|c|}
\hline \multicolumn{5}{|c|}{ PRIME Station 25,14 July $1996,36 \cdot 82^{\circ} \mathrm{N}, 19 \cdot 24^{\circ} \mathrm{W}$} \\
\hline \multirow{2}{*}{$\begin{array}{l}\text { Sample } \\
\text { depth } \\
(\mathrm{m})\end{array}$} & \multicolumn{4}{|c|}{ Fraction $(\%)$ of total bacteria $($ mean $\pm S D)$ detected with each probe } \\
\hline & 645HLI & $645 \mathrm{LL}$ & $405 \mathrm{PRO}$ & CYA664 \\
\hline 3 & $22 \pm 9(950)$ & NC & ND & $24 \pm 9(1048)$ \\
\hline 20 & $13 \pm 9(470)$ & NC & $27 \pm 6(359)$ & $26 \pm 7(561)$ \\
\hline \multirow[t]{2}{*}{40} & $8 \pm 4(940)$ & $3 \pm 3(958)$ & $25 \pm 6(1055)$ & $26 \pm 7(983)$ \\
\hline & 645HLI & 181LL† & 405PRO & CYA664 \\
\hline 80 & $\mathrm{NC}$ & $10 \pm 5(756)$ & ND & $14 \pm 4(983)$ \\
\hline \multicolumn{5}{|c|}{ PRIME Station 26,15 July $199636 \cdot 63^{\circ} \mathrm{N}, 19 \cdot 24^{\circ} \mathrm{W}$} \\
\hline \multirow{2}{*}{$\begin{array}{l}\text { Sample } \\
\text { depth } \\
(\mathrm{m})\end{array}$} & \multicolumn{4}{|c|}{ Fraction $(\%)$ of total bacteria (mean $\pm S D)$ detected with each probe* } \\
\hline & 645HLI & $181 \mathrm{LL}$ & 405PRO & CYA664 \\
\hline 3 & $21 \pm 5(1283)$ & $0 \cdot 5 \pm 0 \cdot 8(647)$ & ND & $23 \pm 10(444)$ \\
\hline 40 & $18 \pm 7(864)$ & $0 \cdot 7 \pm 1 \cdot 2(551)$ & ND & $22 \pm 11(383)$ \\
\hline 80 & $\mathrm{NC}$ & $13 \pm 6(825)$ & ND & $13 \pm 5$ \\
\hline
\end{tabular}

*For the Station 25 samples from 3, 20 and $40 \mathrm{~m}$, the fluorescein-tyramide incubation was carried out for $30 \mathrm{~min}$ whereas the incubation time was extended to $1 \mathrm{~h}$ for the other samples. Numbers in parentheses indicate the total DAPI counts. NC, not counted. ND, not determined.

† For the $80 \mathrm{~m}$ sample of Station 25 and for all depths at Station 26, probe 181LL was used since it gave a higher signal than that of probe $645 \mathrm{LL}$.

samples fixed with glutaraldehyde whereas this was not the case with paraformaldehyde-fixed samples. Thus, subsequent hybridizations and counting were performed with glutaraldehyde-fixed samples. No signals were observed for any of the three samples following hybridization with probe 645HLI. However, good signals were obtained with the other six probes (see above) and the fraction of cells (mean $\pm \mathrm{SD}$ ) hybridizing with each probe as a percentage of total bacteria is shown in Table 3. As for the North Atlantic samples, all of the group-specific probes (CYA664, 405PRO, $405 \mathrm{SYN}$ ) gave very bright signals and the order of signal brightness for the genotype-specific probes was subjectively assessed as 181LL > 1445NATL > 645HLII. Typical signals obtained with probes 405PRO, 645HLII and 181LL are shown in Fig. 3(c-e). For probe 645HLII, the degree of labelling was more variable - some cells seemed only partly labelled, whereas for the other probes, the cells were more uniform in appearance due to even labelling. Despite the variability in labelling, observation of the hybridized filter revealed that HLII Prochlorococcus genotypes were very abundant at all depths and this was reflected in the counts obtained for each depth (Table 3). Interestingly, LL genotypes were also present but were confined to the deepest depth and were also much less abundant than the HLII genotypes. Both LL Prochlorococcus probes (181LL and 1445NATL) gave similar estimations of LL genotypes, suggesting that this population was dominated by
Prochlorococcus genotypes identical or similar to NATL1MIT rather than other LL representatives (such as strains MIT9303, MIT9313, MIT9211, Prochlorococcus marinus sp. SS120) which branch more deeply in the phylogenetic tree (Fig. 1). Synechococcus cell

Table 3. Relative proportions of HLII and LL Prochlorococcus sp. genotypes and total Prochlorococcus and Synechococcus as a percentage of total bacterial counts for the depth profile in the Red Sea

\begin{tabular}{|c|c|c|c|}
\hline \multicolumn{4}{|c|}{ Station A, 18 October $1999,29 \cdot 28^{\circ} \mathrm{N}, 34 \cdot 55^{\circ} \mathrm{E}$} \\
\hline \multirow{2}{*}{$\begin{array}{l}\text { Sample } \\
\text { depth } \\
(\mathrm{m})\end{array}$} & \multicolumn{3}{|c|}{$\begin{array}{c}\text { Fraction }(\%) \text { of total bacteria }(\text { mean } \pm S D) \text { detected } \\
\text { with each probe* }\end{array}$} \\
\hline & 645HLII & $181 \mathrm{LL}$ & 1445NATL \\
\hline 10 & $12 \pm 3(1863)$ & $0 \cdot 2 \pm 0 \cdot 4(1637)$ & $0 \pm 0 \cdot 1(1972)$ \\
\hline 50 & $8 \pm 3(2199)$ & $0 \cdot 2 \pm 0 \cdot 3(2287)$ & $0 \cdot 1 \pm 0 \cdot 2(2236)$ \\
\hline \multirow[t]{2}{*}{100} & $8 \pm 3(1780)$ & $2 \pm 1(2034)$ & $2 \pm 1(1742)$ \\
\hline & 405PRO & $405 S Y N$ & CYA664 \\
\hline 10 & $15 \pm 5(1846)$ & $0 \cdot 7 \pm 0 \cdot 5(1840)$ & $17 \pm 4(1971)$ \\
\hline 50 & $18 \pm 4(2280)$ & $0 \cdot 7 \pm 0 \cdot 6(2287)$ & $18 \pm 3(2335)$ \\
\hline 100 & $14 \pm 5(1652)$ & $0 \cdot 7 \pm 0 \cdot 6(1450)$ & $17 \pm 4(1850)$ \\
\hline
\end{tabular}

* Numbers in parentheses indicate the total DAPI counts. 
(a)

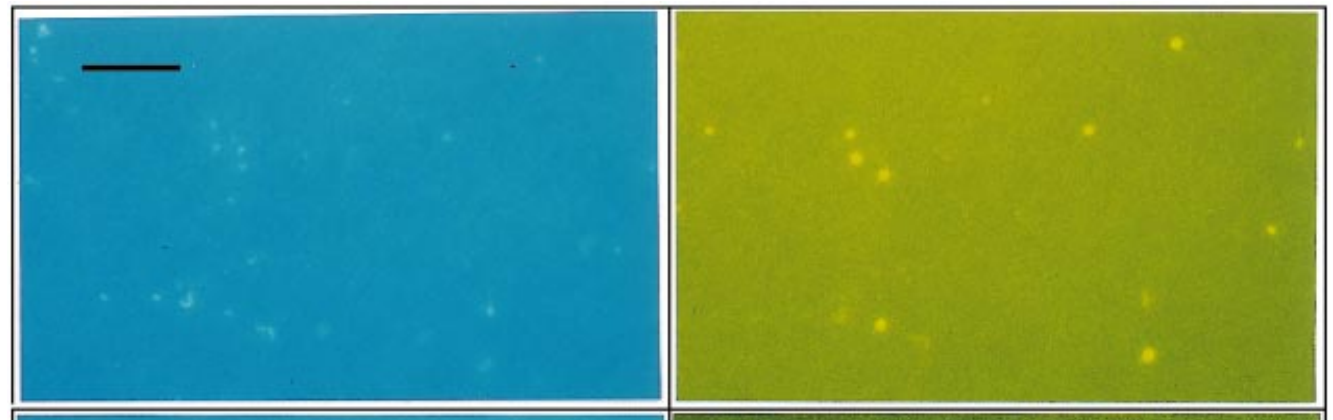

(b)

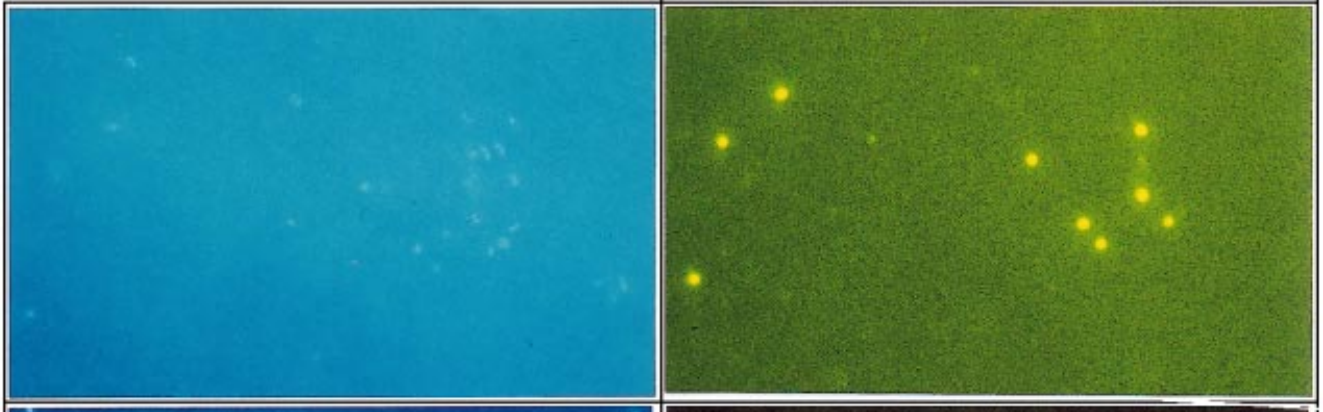

(c)
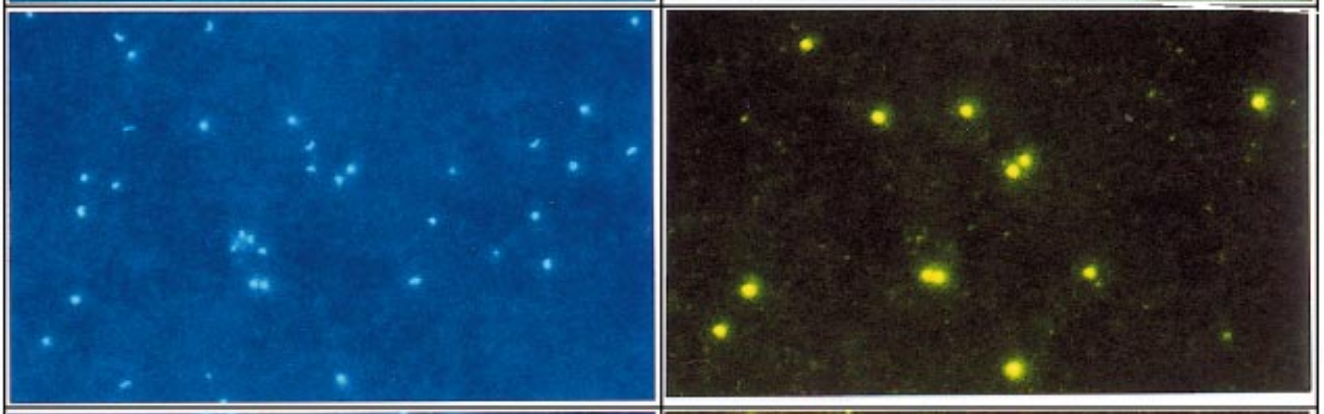

(d)
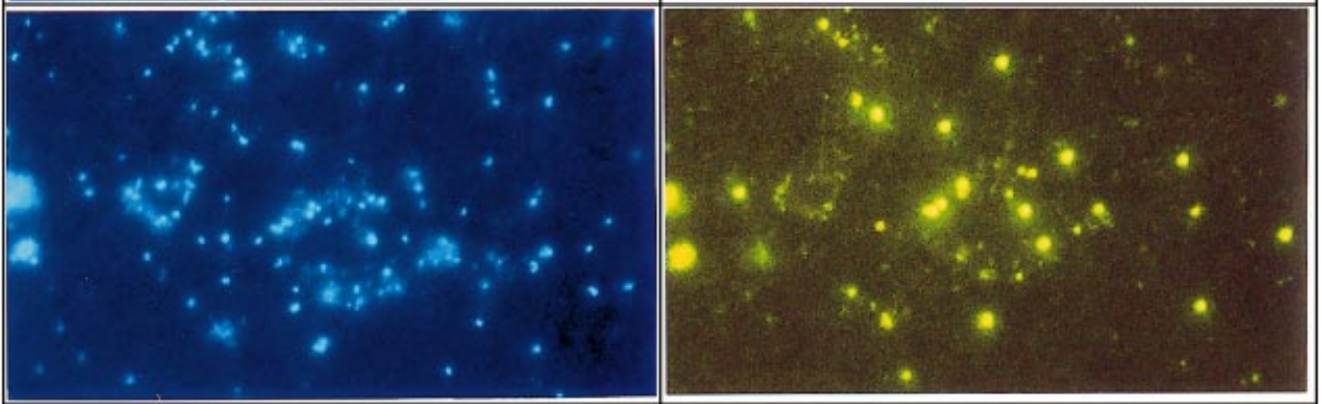

(e)
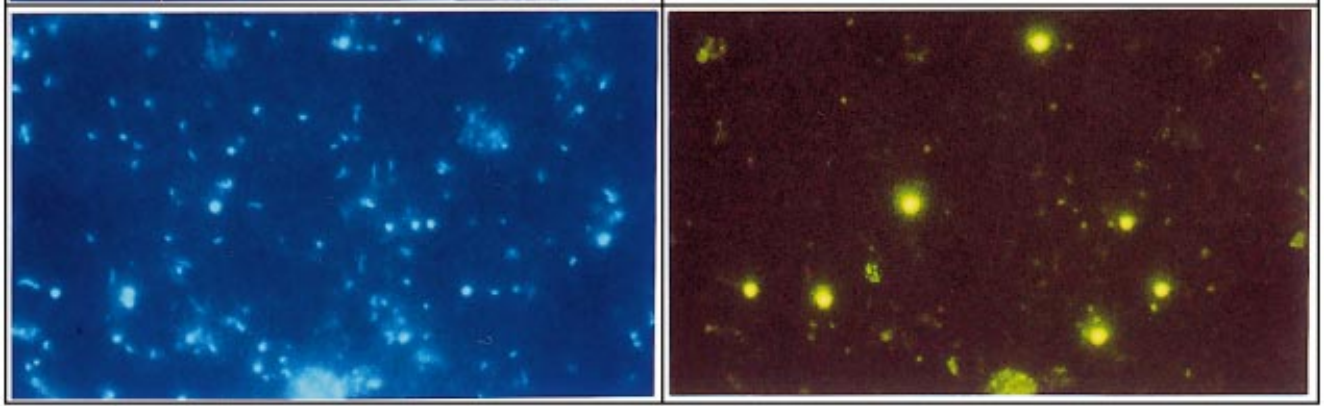

Fig. 3. Colour micrographs of natural samples from the North Atlantic Ocean and the Red Sea after hybridization. (a, b), samples from $3 \mathrm{~m} \mathrm{(a)}$ and $80 \mathrm{~m}$ (b) from the North Atlantic Station 26, hybridized to 645HLI and 181LL respectively, and shown by DAPI staining using filter set 01 (left) and by epifluorescence using filter set 09 (right). (c) Sample from $50 \mathrm{~m}$ from the Red Sea Station A, hybridized to 405PRO and shown by DAPI staining using filter set U-MWU (left) and by epifluorescence using filter set U-MNB (right). (d, e), sample from $100 \mathrm{~m}$ from the Red Sea Station A, hybridized to probes $645 \mathrm{HLII}$ and $181 \mathrm{LL}$ respectively, and shown by DAPI staining using filter set U-MWU (left) and by epifluorescence using filter set U-MNB (right). Bar, $10 \mu \mathrm{m}$. 

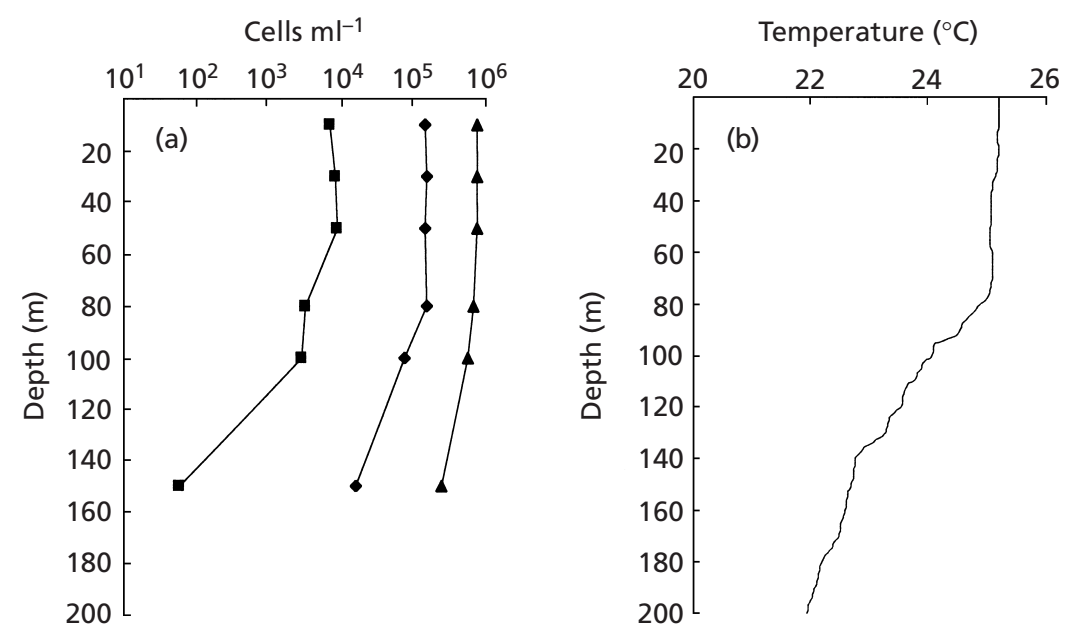

Fig. 4. (a) Flow cytometric data of Prochlorococcus $(\diamond)$, Synechococcus $(\boldsymbol{\square})$ and heterotrophic bacteria $(\boldsymbol{\Delta})$ cell numbers, and (b) the temperature profile for the water column on 18 October 1999 at Station A in the Red Sea.

Table 4. Relative proportions of Prochlorococcus, and Prochlorococcus + Synechococcus, expressed as a percentage of total bacteria as determined by in situ hybridization using probes 405 PRO and CYA664 respectively or by flow cytometry for the depth profile in the Red Sea

The abundance of Prochlorococcus, Synechococcus and total bacteria (Prochlorococcus + Synechococcus + heterotrophic bacteria) as determined by flow cytometry is also presented.

\begin{tabular}{|c|c|c|c|c|c|c|c|}
\hline \multirow{3}{*}{$\begin{array}{l}\text { Depth } \\
\text { (m) }\end{array}$} & \multicolumn{3}{|c|}{ Flow cytometry data (cells $\mathrm{ml}^{-1}$ ) } & \multirow{2}{*}{\multicolumn{2}{|c|}{$\begin{array}{l}\% \text { Prochlorococcus } \\
\text { (as a proportion of } \\
\text { total bacteria) }\end{array}$}} & \multirow{2}{*}{\multicolumn{2}{|c|}{$\begin{array}{c}\% \text { Prochlorococcus }+ \\
\text { Synechococcus (as a } \\
\text { proportion of total bacteria) }\end{array}$}} \\
\hline & Prochlorococcus & Synechococcus & Total & & & & \\
\hline & & & & $\begin{array}{c}\text { Flow } \\
\text { cytometry }\end{array}$ & $\begin{array}{c}\text { ISH* }^{*} \\
(405 \mathrm{PRO})\end{array}$ & $\begin{array}{c}\text { Flow } \\
\text { cytometry }\end{array}$ & $\begin{array}{c}\text { ISH }^{*} \\
(\mathrm{CYA664)}\end{array}$ \\
\hline 10 & 144835 & 7124 & 799771 & $18 \cdot 1$ & $15 \pm 5$ & $19 \cdot 0$ & $17 \pm 4$ \\
\hline 50 & 144387 & 8787 & 771098 & $18 \cdot 7$ & $18 \pm 4$ & $19 \cdot 9$ & $18 \pm 3$ \\
\hline 100 & 78988 & 2945 & 592609 & $13 \cdot 3$ & $14 \pm 5$ & $13 \cdot 8$ & $17 \pm 4$ \\
\hline
\end{tabular}

*ISH, in situ hybridization.

numbers which were estimated following hybridization with probe $405 \mathrm{SYN}$ were extremely low at all depths in agreement with the flow cytometry data (Fig. 4a). In this stratified water column at Station A (Fig. 4b), Prochlorococcus dominated the picophytoplankton, with cell numbers of $1.4 \times 10^{5} \mathrm{ml}^{-1}$ at depths of $10 \mathrm{~m}$ and $50 \mathrm{~m}$ and $0.79 \times 10^{5}$ cells ml $\mathrm{m}^{-1}$ at $100 \mathrm{~m}$. Prochlorococcus thus accounted for $93-94 \%$ of the picophytoplankton population, whereas Synechococcus contributed 3.5$5.7 \%$.

The combined mean abundance of Prochlorococcus and Synechococcus as a percentage of total bacteria (estimated by hybridization with probe CYA664) was consistent throughout the water column at $17-18 \%$. The estimation of Prochlorococcus abundance by hybridization with probe 405PRO was slightly lower than this value, except for the sample taken at $50 \mathrm{~m}$. At all depths, the combined abundance of Prochlorococcus genotypes was less than estimated with either probe 405PRO or CYA664, but this was particularly marked at $50 \mathrm{~m}$.
The mean fraction of Prochlorococcus, or Prochlorococcus plus Synechococcus, as a percentage of total bacteria as assessed by in situ hybridization was then compared to that estimated by flow cytometry (Table 4). The two independent methods gave similar results although the estimates by in situ hybridization were often slightly lower than those obtained by flow cytometry, except for the $100 \mathrm{~m}$ sample, where the converse was observed.

\section{DISCUSSION}

In view of their ecological importance (Partensky et al., 1999), the development of a whole-cell hybridization technique was attempted for members of the genus Prochlorococcus. However, the signals conferred by monolabelled fluorescent probes were not sufficient to be visualized in these bacteria. A poor positive: negative probe signal ratio was also observed when flow cytometry was used to analyse Prochlorococcus cells 
hybridized with fluorescently labelled DNA oligonucleotides (Worden et al., 2000).

Although initially it seemed possible that the permeability of the cells was inadequate, the success of the HRP-labelled probes combined with the TSA detection system showed this not to be the case. In contrast, the alternative detection system offered by the non-fluorescent, precipitable substrate TETON, although successful in hybridizations with some cyanobacteria (Schönhuber et al., 1999), was not suitable for use in Prochlorococcus. It is possible that, as a consequence of a low rRNA content together with the small cells (less than $0.8 \mu \mathrm{m}$ in diameter) typical for members of this genus, the number of probe-conferred HRP molecules is too low to allow the formation of sufficient oxidized substrate for the production of a visible precipitate (Schönhuber et al., 1999). For a given tyramide incubation time, the fluorescent signals from cells of cultured Prochlorococcus marinus and Prochlorococcus $\mathrm{sp}$. isolates were significantly brighter than those obtained in situ, particularly in deep-water samples. An explanation for the lower hybridization signals observed in cells of Prochlorococcus sp. from natural samples may be a low rRNA content per cell due to slow growth. Indeed, cell cycle analysis of natural Prochlorococcus sp. populations in the equatorial Pacific Ocean has revealed that deep populations grow more slowly than surface populations (Vaulot et al., 1995). However, since surface populations may exhibit growth rates equivalent to those observed in cultured isolates (about one doubling per day) (Moore \& Chisholm, 1999), there must be additional factors which may contribute to the reduced hybridization signals observed in natural samples. It is possible that there are structural or physiological differences between cultured isolates and natural populations that, in the latter, decrease the permeability of the cells or perhaps reduce the accessibility of the $16 \mathrm{~S}$ rRNA target sites.

For the initial enumerations made at Station 25, the mean fraction of cells detected by the genotype-specific probes $645 \mathrm{HL}$ and $645 \mathrm{LL}$ was too low to account for the total number of Prochlorococcus sp. determined either with CYA664 or 405PRO. However, the replacement of probe $645 \mathrm{LL}$ by probe $181 \mathrm{LL}$, and the extension of the fluorescein-tyramide incubation time, enhanced the signals so that the mean fraction of cells hybridizing with the genotype-specific probes was raised to the level determined with the CYA664 probe. Thus it is most likely that in the earlier enumerations a proportion of the hybridizing cells gave signals that fell below the detection threshold, rather than the discrepancies in the analyses being due to the existence of genotypes other than those that can be recognized by the three genotypespecific probes employed. The dominance of Prochlorococcus sp., the observed transition of HLI- to LLadapted genotypes from surface to deep waters respectively, and the absence of HLII genotypes from these particular sampling stations in the North Atlantic Ocean, are entirely consistent with previous molecular data (West \& Scanlan, 1999). The degree of variation of the data as observed by the mean $\pm S D$ values was relatively high due to the low numbers of cells and their uneven distribution on the filters. Nevertheless, there was good agreement between the mean fractions of total Prochlorococcus as a percentage of total bacteria as assessed by probes 405PRO and CYA664 compared to the sum of the two Prochlorococcus genotypes.

In situ hybridization of Prochlorococcus cells sampled from the Red Sea revealed a remarkably different community structure, both in the genotypes present and in their vertical distribution. Despite the stratification of the water column (Fig. 4b), HLII genotypes were dominant at all depths and even outnumbered LL genotypes by around 4 times at $100 \mathrm{~m}$, the only depth at which LL genotypes were observed in significant numbers. The dominance of HLII genotypes in this oceanic region is further supported by the retrieval of environmental sequences of the ntcA gene (encoding a cyanobacterial-specific transcriptional activator involved in global nitrogen control) since they were found to cluster together with the $n t c A$ genes of HLII cultured Prochlorococcus strains (Lindell, 2000). The ability of HLII genotypes to colonize the euphotic zone from the surface to a depth below the $1 \%$ light level is remarkable and differs from the Prochlorococcus community structure in the eastern North Atlantic Ocean, where the HL- and LL-adapted populations were clearly partitioned (West \& Scanlan, 1999) (see Table 2). The data for the Red Sea are consistent with flow cytometric observations on samples from the same water column in November 1998 that contained dimly fluorescent (HLadapted) Prochlorococcus cells from surface water down to $120 \mathrm{~m}$. This depth distribution partly overlapped with that of strongly fluorescent (LL-adapted) cells that were observed from $80 \mathrm{~m}$ down to $175 \mathrm{~m}$ (A. F. Post, unpublished results). Photophysiological studies of HLadapted Prochlorococcus strains have not indicated that the HLII genotype strains have greater photoacclimative abilities than HLI genotype strains (Moore \& Chisholm, 1999). However, these studies also revealed that at light levels corresponding to a depth of $118 \mathrm{~m}$, some HL- and LL-adapted strains had similar growth rates, which may help explain the coexistence of HLII and LL Prochlorococcus at $100 \mathrm{~m}$ in the Red Sea. It is possible that in deeper layers the HLII cells are present but are growing slowly. Therefore it would be very interesting to carry out an in situ hybridization study in parallel with flow cytometric cell cycle analysis (see Vaulot et al., 1995 ) in order to estimate the growth rates of cells at different depths.

Despite the use of a tyramide incubation time of $1 \mathrm{~h}$, hybridization of the genotype-specific probes to the Red Sea samples gave a lower estimation of Prochlorococcus cell numbers compared to the group-specific probes. This may be explained by an underestimation of HLII genotypes due to the lower signal conferred by this probe, or could also be due to the presence of genotypes not targeted by our probes. Since the HLII probe targets a region of the $16 \mathrm{~S}$ rRNA that may be less accessible to oligonucleotides (Fuchs et al., 1998), it is worth testing 
the use of unlabelled helper oligonucleotides which are designed to bind to regions adjacent to that of the target probe and were shown to improve the hybridization signals in E. coli (Fuchs et al., 2000). Future retrieval and sequencing of further Prochlorococcus environmental $16 \mathrm{~S}$ rDNA clones will be required in order to verify that all of the genotypes present are indeed targeted by the probes described here. The statistical variation observed within the Red Sea data was less than that of the North Atlantic samples due to a higher density of cells on the filters, which allowed a greater number of cells to be counted. Despite this variation, the fact that the mean fractions of Prochlorococcus assessed by in situ hybridization agreed so well with Prochlorococcus abundance determined by flow cytometry (Table 4) lends strong credence to the use of this in situ hybridization protocol in quantitative analyses.

The original examination of $16 \mathrm{~S}$ rRNA sequences obtained for a number of Prochlorococcus strains isolated from surface and deep waters from different oceanic regions demonstrated a clear correlation with their depth of isolation (Scanlan et al., 1996) whilst closely related strains were found in different geographical locations such as the Atlantic and Pacific Oceans (Urbach et al., 1998). These findings are extended in this study, which showed that LL genotypes comparable to the NATL1MIT/NATL2B isolates seem to be ubiquitous, having been detected only at depth, but in both the Red Sea and the North Atlantic. However, for the HL genotypes the picture is more complicated. The results presented here, and other preliminary data which show a dominance of HLI in the Mediterranean Sea and HLII in the Sargasso (N. West \& D. Scanlan, unpublished data), indicate that the relative abundance of the two types of HL populations and their vertical distribution may differ significantly with geographical location. This may reflect other more subtle features of the water column itself such as salinity, temperature, prevailing oceanic circulation or the source of the Prochlorococcus 'seed' population.

Our results demonstrate that an in situ hybridization method can be used to rapidly assess the community structure of Prochlorococcus sp. in the natural environment. Moreover, using this technique, estimation of Prochlorococcus abundance, as a proportion of total bacteria, can be directly correlated with flow cytometric data for Prochlorococcus and bacterial cell numbers, and the two independent methods have been shown to compare favourably. The fixation of samples is simple and the analysis does not require time-consuming DNA extraction procedures and is free of the potential biases of the PCR. The counting of cells using epifluorescence microscopy is the most labour-intensive part of the method and this step may be improved in the future by using a laser scanning cytometer for the counting of cells on a filter (Parthuisot et al., 2000) or by optimizing the hybridization method in liquid for analysis by flow cytometry. Both of these methods would allow the rapid counting of large numbers of cells, either at the genus level or of particular genotypes, thus providing very precise estimates of population dynamics. Moreover, by combining in situ hybridization analyses using $16 \mathrm{~S}$ rRNA-targeted oligonucleotides with single-cell immunofluorescence assays for protein markers of nutrient stress (Scanlan et al., 1997), it should be possible to determine the specific physiological state of individual Prochlorococcus sp. genotypes. Such a multiple-probing approach will be essential to elucidate the nutritional adaptation and functional importance of the various ecotypes of Prochlorococcus sp. within natural communities.

\section{ACKNOWLEDGEMENTS}

This work was supported in part by NERC grant GST/ 02/1081 (PRIME thematic programme), NERC grant GR3/ 11606 and by the EU grants MAS3-CT97-0128 (PROMOLEC) and EVK3-CT-1999-00021 (PICODIV). W. A. Schönhuber, R. I. Amann and R. Rippka were supported in part by contract BIO4-CT96-0256 (BASIC) of the European programme BIOTECH (Life Sciences and Technologies, Biotechnology Programme, 1994-1998). R. Rippka also acknowledges support by the Institut Pasteur and the Centre National de la Recherche Scientifique (CNRS, URA 2172). W. A. Schönhuber held a Marie Curie Fellowship from the EC (contract no. EVK1-CT1999-50002) with the Institut Pasteur as host institution. This is PRIME contribution number 126. D. J. Scanlan is a Royal Society University Research Fellow.

We thank Thérèse Coursin (Institut Pasteur) for making available the 16S rRNA sequence of Prochlorococcus sp. strain PCC 9511 prior to publication, Mike Zubkov for providing the PRIME natural samples and for helpful discussions, Dominique Marie for Red Sea flow cytometric data, and Fred Partensky, Jean Blanchot, Florence Legall and Solange Legall for providing Prochlorococcus sp. cultures.

\section{REFERENCES}

Amann, R. I., Binder, B. J., Olson, R. J., Chisholm, S. W., Devereux, R. \& Stahl, D. A. (1990). Combination of $16 \mathrm{~S}$ ribosomal RNAtargeted oligonucleotide probes with flow cytometry for analyzing mixed microbial populations. Appl Environ Microbiol 56, 1919-1925.

Amann, R. I., Zarda, B., Stahl, D. A. \& Schleifer, K.-H. (1992). Identification of individual prokaryotic cells with enzyme-labeled, rRNA-targeted oligonucleotide probes. Appl Environ Microbiol 58, 3007-3011.

Amann, R. I., Ludwig, W. \& Schleifer, K. H. (1995). Phylogenetic identification and in situ detection of individual microbial cells without cultivation. Microbiol Rev 59, 143-169.

Amann, R., Glöckner, F. O. \& Neef, A. (1997). Modern methods in subsurface microbiology : in situ identification of microorganisms with nucleic acid probes. FEMS Microbiol Rev 20, 191-200.

Binder, B. J. \& Liu, Y. C. (1998). Growth rate regulation of rRNA content of a marine Synechococcus (cyanobacterium) strain. Appl Environ Microbiol 64, 3346-3351.

Brosius, J., Dull, T., Sleeter, D. D. \& Noller, H. F. (1981). Gene organization and primary structure of a ribosomal RNA operon from Escherichia coli. J Mol Biol 148, 107-127.

Capone, D. G., Zehr, J. P., Paerl, H. W., Bergman, B. \& Carpenter, E. J. (1997). Trichodesmium, a globally significant marine cyanobacterium. Science 276, 1221-1229.

Chisholm, S. W., Frankel, S. L., Goericke, R., Olson, R. J., Palenik, B., Waterbury, J. B., Westjohnsrud, L. \& Zettler, E. R. (1992). 
Prochlorococcus marinus nov. gen. nov. sp.: an oxyphototrophic marine prokaryote containing divinyl chlorophyll $a$ and $b$. Arch Microbiol 157, 297-300.

Ferris, M. J. \& Palenik, B. (1998). Niche adaptation in ocean cyanobacteria. Nature 396, 226-228.

Fuchs, B. M., Wallner, G., Beisker, W., Schwippl, I., Ludwig, W. \& Amann, R. (1998). Flow cytometric analysis of the in situ accessibility of Escherichia coli 16S rRNA for fluorescently labeled oligonucleotide probes. Appl Environ Microbiol 64, 4973-4982.

Fuchs, B. M., Glöckner, F. O., Wulf, J. \& Amann, R. (2000). Unlabeled helper oligonucleotides increase the in situ accessibility to $16 \mathrm{~S}$ rRNA of fluorescently labeled oligonucleotide probes. Appl Environ Microbiol 66, 3603-3607.

Glöckner, F. O., Amann, R., Alfreider, A., Pernthaler, J., Psenner, R., Trebesius, K. \& Schleifer, K. H. (1996). An in-situ hybridization protocol for detection and identification of planktonic bacteria. Syst Appl Microbiol 19, 403-406.

Jacquet, S., Lennon, J. F., Marie, D. \& Vaulot, D. (1998). Picoplankton population dynamics in coastal waters of the northwestern Mediterranean Sea. Limnol Oceanogr 43, 1916-1931.

Lebaron, P., Catala, P., Fajon, C., Joux, F., Baudart, J. \& Bernard, L. (1997). A new sensitive, whole cell hybridization technique for detection of bacteria involving a biotinylated oligonucleotide probe targeting rRNA and tyramide signal amplification. Appl Environ Microbiol 63, 3274-3278.

Lindell, D. (2000). Assessing the nitrogen status of marine prokaryotic phytoplankton using molecular methods. PhD thesis, Hebrew University of Jerusalem.

Lindell, D. \& Post, A. F. (1995). Ultraphytoplankton succession is triggered by deep winter mixing in the Gulf of Aqaba (Eilat), Red Sea. Limnol Oceanogr 40, 1130-1141.

Manz, W., Amann, R., Ludwig, W., Wagner, M. \& Schleifer, K.-H. (1992). Phylogenetic oligodeoxynucleotide probes for the major subclasses of proteobacteria: problems and solutions. Syst Appl Microbiol 15, 593-600.

Moore, L. R. \& Chisholm, S. W. (1999). Photophysiology of the marine cyanobacterium Prochlorococcus: ecotypic differences among cultured isolates. Limnol Oceanogr 44, 628-638.

Moore, L. R., Rocap, G. \& Chisholm, S. W. (1998). Physiology and molecular phylogeny of coexisting Prochlorococcus ecotypes. Nature 393, 464-467.

Neilan, B. A., Jacobs, D., Del Dot, T., Blackall, L. L., Hawkins, P. R., Cox, P. T. \& Goodman, A. E. (1997). rRNA sequences and evolutionary relationships among toxic and nontoxic cyanobacteria of the genus Microcystis. Int J Syst Bacteriol 47, 693-697.

Otsuka, S., Suda, S., Li, R. H., Watanabe, M., Oyaizu, H., Matsumoto, S. \& Watanabe, M. M. (1998). $16 \mathrm{~S}$ rDNA sequences and phylogenetic analyses of Microcystis strains with and without phycoerythrin. FEMS Microbiol Lett 164, 119-124.

Partensky, F., Hess, W. R. \& Vaulot, D. (1999). Prochlorococcus, a marine photosynthetic prokaryote of global significance. Microbiol Mol Biol Rev 63, 106-127.

Parthuisot, N., Catala, P., Lemarchand, K., Baudart, J. \& Lebaron, P. (2000). Evaluation of ChemChrome V6 for bacterial viability assessment in waters. J Appl Microbiol 89, 370-380.

Rippka, R., Coursin, T., Hess, W. \& 7 other authors (2000). Prochlorococcus marinus Chisholm et al., 1992 subsp. pastoris subsp. nov. strain PCC 9511, the first axenic chlorophyll $a_{2} / b_{2^{-}}$ containing cyanobacterium (Oxyphotobacteria). Int J Syst Evol Microbiol 50, 1833-1847.

Scanlan, D. J., Hess, W. R., Partensky, F., Newman, J. \& Vaulot, D. (1996). High degree of genetic variation in Prochlorococcus (Prochlorophyta) revealed by RFLP analysis. Eur J Phycol 31, $1-9$.

Scanlan, D. J., Silman, N. J., Donald, K. M., Wilson, W. H., Carr, N. G., Joint, I. \& Mann, N. H. (1997). An immunological approach to detect phosphate stress in populations and single cells of photosynthetic picoplankton. Appl Environ Microbiol 63, 2411-2420.

Schönhuber, W., Fuchs, B., Juretschko, S. \& Amann, R. (1997). Improved sensitivity of whole-cell hybridization by the combination of horseradish peroxidase-labeled oligonucleotides and tyramide signal amplification. Appl Environ Microbiol 63, 3268-3273.

Schönhuber, W., Zarda, B., Eix, S., Rippka, R., Herdman, M., Ludwig, W. \& Amann, R. (1999). In situ identification of cyanobacteria with horseradish peroxidase-labeled, rRNAtargeted oligonucleotide probes. Appl Environ Microbiol 65, 1259-1267.

Urbach, E. \& Chisholm, S. W. (1998). Genetic diversity in Prochlorococcus populations flow cytometrically sorted from the Sargasso Sea and Gulf Stream. Limnol Oceanogr 43, 1615-1630.

Urbach, E., Scanlan, D. J., Distel, D. L., Waterbury, J. B. \& Chisholm, S. W. (1998). Rapid diversification of marine picophytoplankton with dissimilar light-harvesting structures inferred from sequences of Prochlorococcus and Synechococcus (Cyanobacteria). J Mol Evol 46, 188-201.

Urdea, M. S., Warner, B. D., Running, J. A., Stempien, M., Clyne, J. \& Horn, T. (1988). A comparison of non-radioisotopic hybridization assay methods using fluorescent, chemiluminescent, and enzyme labeled synthetic oligodeoxyribonucleotide probes. Nucleic Acids Res 16, 4937-4956.

Vaulot, D., Marie, D., Olson, R. J. \& Chisholm, S. W. (1995). Growth of Prochlorococcus, a photosynthetic prokaryote, in the equatorial Pacific Ocean. Science 268, 1480-1482.

Wallner, G., Amann, R. \& Beisker, W. (1993). Optimizing fluorescent in situ hybridization with ribosomal RNA-targeted oligonucleotide probes for flow cytometric identification of microorganisms. Cytometry 14, 136-143.

West, N. J. \& Scanlan, D. J. (1999). Niche-partitioning of Prochlorococcus populations in a stratified water column in the eastern North Atlantic Ocean. Appl Environ Microbiol 65, 2585-2591.

von Wintzingerode, F., Göbel, U. B. \& Stackebrandt, E. (1997). Determination of microbial diversity in environmental samples: pitfalls of PCR-based rRNA analysis. FEMS Microbiol Rev 21, 213-229.

Worden, A. Z., Chisholm, S. W. \& Binder, B. J. (2000). In situ hybridization of Prochlorococcus and Synechococcus (marine cyanobacteria) spp. with rRNA-targeted peptide nucleic acid probes. Appl Environ Microbiol 66, 284-289.

Wyman, M., Gregory, R. P. F. \& Carr, N. G. (1985). Novel role for phycoerythrin in a marine cyanobacterium, Synechococcus strain DC2. Science 230, 818-820.

Received 20 November 2000; revised 14 March 2001; accepted 28 March 2001. 